\title{
High Poet: The Life and Work of Philip Lamantia
}

Late in life, Philip Lamantia drafted fragments of a memoir under the working title High Poet. He regarded himself as a "high poet" in more than one sense: he was a visionary poet who ascended the heights of pure imagination, one who sought both intellectual understanding and spiritual transcendence. He was also a poet of vast erudition, one for whom learning was equivalent to gnosis; in his wide-ranging reading, he drew out the poetic essence of the sciences, philosophy, and history, which he then infused into his own writing. He welcomed (and sometimes provoked) visions, through such vehicles as meditation, religious ceremony, and psychotropic substances. His quest led outward as well as inward: in 1944, at age sixteen, Lamantia left high school in his native San Francisco to join the company of war-exiled Parisian surrealists in New York; and through the 1950s and 1960s, he lived and wrote in Mexico, Morocco, France, Italy, Spain, and Greece.

Throughout his poetic itinerary, Lamantia would traverse the ecstatic space between writing poetry and religious mysticism, at times rejecting both, then discovering aspects of one within the other-until finally, in the last decade of his life, arriving at a synthesis of scholarly erudition and spiritual discernment. Lamantia's high aspiration as a poet is evident in his desire-stated in a late interview-to achieve a "miracle in words."

In tandem with an alternation between the polarities of poetry and mysticism, Lamantia struggled with a lifelong manic-depressive condition. Bipolar episodes, which could take the form of spiritual crises, led him to withdraw from society for long periods, to suppress his own work from publication, and even, on occasion, to destroy it. As a result, Lamantia maintained a hermetic presence in American poetry, even as he played a seminal role in some of its most innovative developments, both through his participation in mentor Kenneth Rexroth's anarchist Libertarian Circle of poets and scholars, subsequently a major component of the San Francisco Renaissance, and through his later involvement with the Beat Generation. As Rexroth would later write, "a great deal of what has happened since in poetry was anticipated in the poetry Lamantia wrote before he was 21."

Even the barest summary of Lamantia's subsequent life bristles with incident. In the mid-I950s, he partook in rituals with the Washoe Indians at Lake Tahoe, 
Nevada, and with the Cora Indians (Nayarit) in Mexico. In 1955, between stays in Mexico, Lamantia participated in the famous Six Gallery reading in San Francisco where Allen Ginsberg first read "Howl." Two years later, shortly after the publication of Jack Kerouac's On the Road (1957), Lamantia gave what are widely considered to be the first public jazz poetry readings, with Kerouac, Howard Hart, and musician David Amram. Yet by 1960, even as he was featured in Donald Allen's groundbreaking anthology, New American Poetry: 1945-1960, Lamantia had renounced poetry, burning most - though not all—of his unpublished work. In late 1962, he left America for Europe, devoting himself to the study of Egyptian symbology and Renaissance hermetic traditions-yet in 1965 , after meeting his future wife, Nancy Peters, he dramatically returned to both poetry and surrealism, beginning his long association with City Lights Books with the 1967 publication of his Selected Poems: 1943-1966. In the early '70s, after returning to San Francisco, he affiliated himself with the Chicago Surrealist Group, led by Franklin and Penelope Rosemont, contributing to its journal Arsenal while remaining aloof from both mainstream literary culture and the constructivist aesthetics of language poetry. The 1980 s would reveal an increasing ecological consciousness in his poetry, manifesting itself through his exploration of the Pacific Coast wilderness, ornithology, and Native American cultures. His ongoing interest in Egypt culminated in a long poem of that title, inspired by his 1989 visit to the monuments at Luxor.

By the mid-' 90 s, Lamantia had largely fallen silent due to severe depression, though he would reemerge after the publication of Bed of Sphinxes: New and Selected Poems 1943-1993 in 1997 and a brief return to Catholicism following a 1998 vision in the National Shrine of Saint Francis of Assisi in San Francisco's North Beach. This final burst of poetic activity resulted in a handful of published poems before he fell silent once again, in late 200I. He spent the rest of his life withdrawn from the world. On his death in 2005, the New York Times acknowledged Lamantia's vital contribution to twentieth-century poetry by quoting French literary critic Yves le Pellec, who once identified him as "a living link between French surrealism and the American counterculture at its beginnings."3

\section{EARLY LIFE}

Philip Nunzio Lamantia was born at home, at i7 Is Sanchez Street, in San Francisco, on October 23, 1927, the only child of Sicilian immigrants Nunzio and Mary Lamantia. His paternal grandmother, Mattea, also lived with the family, and among Philip's earliest memories were the Sicilian folktales she told him in her backyard rose garden. Nunzio had immigrated from Palermo to the United States in his late teens and had served in the American army in World War I. Mary (née Tarantino) came from a large, impoverished family from the tiny Sicilian island of Ustica; her oldest brother, Paul Tarantino, a produce distributor, served as the head of the family. After the war, 
Nunzio was hired by Tarantino as a produce broker, becoming known in the trade by the Anglicized name "Nelson." Nunzio became successful enough to buy a house on Russia Avenue in San Francisco's Excelsior district, then on the outskirts of the city, where Philip spent most of his childhood.

Throughout his childhood, Lamantia was drawn to what the surrealists called "the marvelous"-manifestations of the uncanny, the sublime, or the impossible, that resist or exceed rationalization. On the one hand, this is perfectly ordinary, insofar as surrealism associates the ability to perceive the marvelous with the unfettered imagination of childhood. On the other hand, Lamantia's childhood taste for the marvelous-insofar as it can be known —is remarkably consistent with his adult purchase on the topic. Among his papers, for example, are two scrapbooks containing newspaper comics depicting scenes from exotic cultures as well as illustrations from Ripley's Believe It or Not, asserting the marvelous as fact. As noted in his essay "Radio Voices: A Child's Bed of Sirens," Lamantia also gravitated toward what he calls "mystery fantasies," whose characters powerfully resonated in all media: comics, movies, and radio. "I can trace a profound awakening of the poetic sense of life and language directly to the exemplary magical myth of The Shadow." "On the poetic plane," he continues, "The Shadow and Mandrake are paragons of hermetic knowledge: modern forms, respectively, of the fairy tale wonder-worker and the sorcerer." 6

That these uncanny, fantastic elements of pop culture influenced the poetics of the precocious Lamantia is evident from his earliest days as a poet. Lamantia first began writing poetry in middle school, under the tutelage of a flaming-haired Irish immigrant named Griffin, whose English classes consisted purely of the reading and discussion of poetry and whose standing policy was that anyone who wrote a poem didn't have to do that evening's homework. Lamantia's choice to embark on an orientalist fantasia modeled on Edward FitzGerald's Rubaiyat of Omar Khayyam already seems characteristic of his prior interest in the marvelous (even as its inherently openended nature allowed him to avoid homework indefinitely). From the Rubaiyat, Lamantia would move on to Edgar Allan Poe, thus placing himself directly in touch with one of surrealism's earliest acknowledged forebears. "Poe," André Breton writes in the first "Manifesto of Surrealism" (1924), "is surrealist in adventure," consonant with Lamantia's poetic reading of "night-beings" like the Shadow.

Nothing from Lamantia's Rubaiyat survives; nonetheless, the poem impressed the adults in his life with its level of accomplishment, leading to his own selfidentification as a poet by age fourteen. According to his autobiographical notes, his poetic vocation came to him on the top of San Bruno Mountain, after observing the weird effects of the winds and fog banks that surrounded it, evidence of his response to the marvels of the natural world. ${ }^{8}$ There, in the center of a "classic grove of trees," he heard "an inner voice declaring me a poet." Lamantia noted that "it was there on that mountain that I wrote my first modernist poem 'Paranoid Dream."” This poem was not preserved, though another from this time, "Ages in the Wind," survives, 
due to its appearance in the 1943 installment of The Young West Sings: Anthology of California High School Poetry - his first publication. With its reference to the "dark cultures and ages" and "the Nile," "Ages in the Wind" appears to allude to Lamantia's burgeoning interest in the mysteries of past civilizations, fueled in part by a visit around this time to the library of the Philosophical Research Society, established by Manly P. Hall in 1936, in Los Angeles.

\section{ENCOUNTER WITH SURREALISM}

"Paranoid Dream" seems to reflect (or even to anticipate) the young poet's encounter with the "paranoia-critical method" of renegade surrealist Salvador Dalí, whose paintings were exhibited in a retrospective at the San Francisco Palace of the Legion of Honor in the spring of the year that this poem was written, $1942 .{ }^{9}$ The Dalí exhibition, along with a nearly concomitant retrospective of the works of Joan Miró at the San Francisco Museum of Art, brought surrealism to the attention of the teenaged Lamantia with all the force of a revelation. Here was a worldview and a practice that could accommodate the unsettling modes of consciousness that were already flowering in him. Lamantia would reiterate, throughout his life, the lessons learned from these two exhibitions: that surrealism is not a style (as demonstrated by the contrast between Dalís classical figuration and Miró's semiabstraction) but a transmogrification of art-and ultimately of reality itself-into something other. Moreover, the citations from surrealist texts that accompanied the paintings were electrifying in their own right. These texts seemed, as Lamantia later attested, to flow into the paintings themselves, aspiring toward the supreme point (posited by André Breton) where conventional categories - between word and image, sleep and waking, reason and madness, life and death—are abolished.

After viewing these examples of surrealist painting, Lamantia resolved to practice surrealist writing - seized with the notion, as he explained many years later in his lectures at the San Francisco Art Institute, that paintings and poems were interchangeable manifestations of the same unsayable, unpictureable sur-reality. ${ }^{10}$ Following his visits to these exhibitions, Lamantia scoured the San Francisco Public Library for materials relating to surrealism and came up with only a handful of books, among them David Gascoyne's A Short Survey of Surrealism (1935), Julien Levy's Surrealism (1936), and Georges Lemaitre's From Cubism to Surrealism in French Literature (194I). On newsstands, Lamantia found issues of View, a glossy, New York-based avant-garde magazine that often featured surrealist art and writing; he immediately ordered the surrealist books advertised in its pages. Lastly, in the library of the San Francisco Museum of Art, Lamantia discovered two issues of the lavishly produced $V V V$, a magazine emanating from the New York circle of European surrealists in exile during World War II.

Thus inspired, Lamantia, by his own account, "in no time had a dozen poems ready," which he ventured to submit to the editors of View magazine. ${ }^{11}$ Five of 
these- "I Am Coming," "Apparition of Charles Baudelaire," "The Ruins," "By the Curtain of Architecture," and "There Are Many Pathways to the Garden"-were accepted for publication in the June 1943 issue, and another poem, "Automatic World," appeared in the subsequent (October) issue. The power and originality of these works - written by a fifteen-year-old_caused Lamantia to be hailed by the New York avant-garde as a kind of American Rimbaud. A flurry of correspondence ensued between Lamantia and View editors Charles Henri Ford and Parker Tyler. After his subsequent discovery of $V V V$, the young poet wrote directly to surrealist leader André Breton and enclosed some poems for his consideration.

Breton at that time was much concerned with the survival of the surrealist project, which was facing, in the midst of the wartime dispersal of its key practitioners, increasingly hostile criticism declaring the movement to be irrelevant and outmoded. Not long before Lamantia's emergence on the scene, Breton had given a lecture at Yale University on "The Situation of Surrealism between the Two Wars" in which he emphasized, with an eye toward the next generation, that surrealism "was born of a limitless affirmation of faith in the genius of youth." He therefore welcomed the advent of a young American poet of genius, accepting three of Lamantia's poems"The Islands of Africa” (dedicated to Rimbaud), "The Touch of the Marvelous," and "Plumage of Recognition"-for publication in $V V V$ and praising him as "a voice that rises once in a hundred years." Breton also asked Lamantia to compose a statement clarifying his relation to surrealism; this statement— "Surrealism in 1943"-appeared in the final double issue of $V V V$ alongside Lamantia's poems.

In this brief statement, Lamantia brought everything he had learned about surrealism in the previous year into focus, and especially made a point of citing Breton's Second Manifesto. "Surrealism," Lamantia wrote, "is fundamentally a philosophy endeavoring to form a unity between particular opposite forces... Surrealism carries this dialectic process to one of its farthest points." He fully embraced the role that he sensed Breton wanted him to fill, that of a bringer of youthful vitality to the movement, proclaiming that "the voice of Lautréamont, pure, young and feeding the fire that has begun to issue from my depths, is again heard." Lamantia added the proviso that, since he was "only fifteen years old," his opinions would "inevitably change to a certain extent." It would turn out to be a prescient comment: by the end of the following year, he would renounce his adherence to surrealism. Lamantia would wrestle — as in a "dialectic process"-with many other visionary and esoteric worldviews before finally formulating his own version of surrealism in later life.

For the moment, however, the young poet was still flushed with the excitement of his recognition by the surrealists in New York. In contrast to his literary success, he had been experiencing difficulties at home and at school, mostly due to his precocious intelligence and rebellious behavior. In early 1944, Lamantia and his father were called into a meeting with the principal of Balboa High School, who, attempting to get Philip to conform to school regulations, invoked the Depression-era phrase 


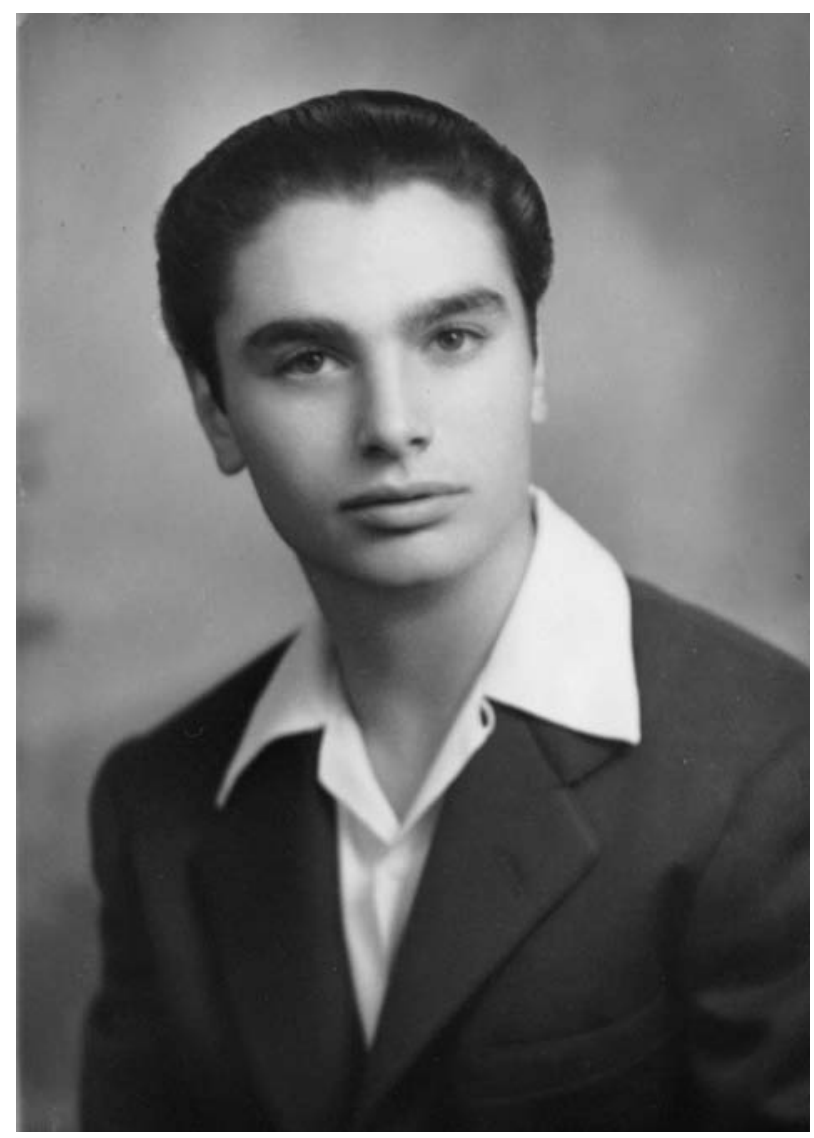

First author photo, San Francisco, 1943. Courtesy of The Bancroft Library, University of California, Berkeley.

"the common man." To the principal's consternation, the young poet shot to his feet and declared, "I am not the common man!" While it resulted in expulsion from Balboa, this display of defiance won the respect of Nunzio Lamantia, who was otherwise mystified by his son's strange pursuits. In April 1944, on the basis of an offer from the editors of View of an editorial assistant position and with the approval of his parents, the sixteen-year-old poet boarded a "gaslit wartime priority train," bound for New York City. ${ }^{12}$

Lamantia thus became known as a poet in New York some time before he participated in the literary scene of his native San Francisco. Nonetheless, soon after his debut in View, Lamantia was contacted by Berkeley-based poet/editor George Leite, who would shortly launch his own magazine, Circle. Leite would publish Lamantia in Circle alongside such international literary figures as Henry Miller, Anaïs Nin, and 
Yvan Goll. More important, on the night before Lamantia's departure for New York, Leite invited him to dinner to meet anarchist-pacifist poet Kenneth Rexroth, thus preparing the way for his entry into the San Francisco milieu of oppositional writers, artists, and intellectuals upon his return to the Bay Area. In An Autobiographical Novel (first published in 1964, revised in 1991), perhaps wishing to claim discovery of the teenage poet, Rexroth presents a highly fictionalized account of their initial meeting that writes Leite out of the picture:

One day I got a telephone call from someone I didn't know who was an English teacher in a high school....

He said, "I am sending you over a student in whom I think you would be interested and who you might be able to help. He is a poet with immense talent."

In a few days, we got a phone call from Philip Lamantia. We asked him to dinner that night. It was an amazing experience. He was about sixteen years old and extremely handsome-a small Italian lad who seemed already to have read most avant-garde literature and who, again, was already the best of the third generation of surrealists.... I have never known anyone else who started out, without preliminaries, with no five-finger exercises or scales, as an achieved poet. ${ }^{13}$

Having published three books of poetry by that time, Rexroth was well versed in avant-garde literature and active in radical politics; he had visited Paris in the twenties, when surrealism was at its height of influence, and even claimed to have met some of the group's members. He had also resided in New York, but ended up rejecting that city's intellectual culture as "too European." Rexroth, robust in body and spirit, was attracted to what he perceived as the wilder side of the American continent, taking up residence in San Francisco in 1927. His influence on the young Lamantia would prove to be both deep and lasting.

As soon as he arrived in Manhattan, Lamantia was plunged into an exhilarating-but at first, undoubtedly bewildering-milieu where he encountered many of the famous surrealists whose work he had studied in the past year. He took up his post as an editorial assistant at View, "mostly rejecting the daily deluge of unsolicited manuscripts.” As Lamantia recalled in a 1998 interview with David Meltzer,

My milieu was mainly among the many English-speaking French and other European painters and intellectuals: Max Ernst, Duchamp, Yves Tanguy, Nicolas Calas, Kurt Seligmann, Pavel Tchelitchew, André Masson, the critic Leon Kochnitsky-and their American counterparts, the writers Harold Rosenberg, Lionel Abel, Parker Tyler, the painter William Baziotes, and Paul Bowles, who introduced me to world music [and, as Lamantia notes elsewhere, to modern jazz, especially bebop]. There were weekly gallery openings, jazz on Fifty-Second Street, endless parties, and almost daily invitations to lunch and dinner. ${ }^{14}$

Lamantia found Breton himself to be less accessible than he may have hoped, partly because of the language barrier (Breton spoke only French), and partly because, as 
Lamantia jotted in his autobiographical notes, Breton was "not social, and didn't go to galleries." Their first encounter occurred by chance, when Breton came by the View offices at I East Fifty-Third Street to sign the contract for a bilingual selection of his poems, Young Cherry Trees Secured against Hares, which View Editions would publish in 1946. This encounter was brief, with Charles Henri Ford acting as translator, but Breton would soon arrange for a more formal and substantial meeting between himself and "le jeune poète américain" at Del Pezzo's Restaurant, where they dined alone, save for the presence of art and music critic Leon Kochnitzky, who translated between the two as they discussed surrealism..$^{15}$

The significance of this dinner-as well as the special introduction to Lamantia's poems in $V V V$ - can be gauged by Breton's oft-criticized aloofness from the New York art milieu. The introduction to an anthology of View, for example, cites Edouard Roditi, the polyglot poet and translator of Young Cherry Trees: "Surrealism proper, Roditi reminds us, was a closed society. 'One must be invited to join, and we never sought admission."'16 While Breton usually withheld his endorsement of their work as surrealist, the New York avant-gardists attracted to European surrealism maintained a sense of independence, refusing to pledge their allegiance to Bretonian principles as Lamantia had. This was especially true of Charles Henri Ford and Parker Tyler, editors of View; while surrealism remained central to their concerns, they sometimes featured material from the wider avant-garde scene. Their "Americana Fantastica" issue, in particular, was intended to showcase the art and writing of a homegrown imagination complementary with, but not beholden to, European surrealism. As Tyler pointedly stated in that issue, the fantastic, "having no home but its own ... cannot be transplanted." ${ }^{17}$

Although his encounters with Breton were infrequent, Lamantia met with the Swiss artist Kurt Seligmann on a weekly basis. Seligmann spoke English fluently and shared his knowledge of magical lore, "graciously" allowing Lamantia to peruse his vast collection of alchemical texts. ${ }^{18}$ Edouard Roditi became a good friend; the two would reunite in San Francisco the following year, when Roditi was working at the United Nations Charter Conference. Lamantia also was introduced to the surrealistinfluenced American filmmaker Maya Deren, who was sufficiently impressed that she gave him a brief role in her film At Land (1944), which also includes appearances by Gregory Bateson, John Cage, and Parker Tyler. Lamantia and Tyler would stay in touch until Tyler's death in 1974 .

As the war came to an end, the European refugees began to return home, and their American counterparts appeared either uninterested in or incapable of perpetuating surrealism in its original form. The transplantation of surrealism to the United States had indeed failed. Moreover, Lamantia had, as he put it, "a fight with Ford" and resigned from View. ${ }^{19}$ Filled with bitterness and disappointment, Lamantia decided to return to San Francisco. At that point, he hadn't seen Breton for some time; indeed, his last encounter with Breton-by chance, in the company of Yves 
Tanguy, at the corner of Fifth Avenue and Fifty-Seventh-was one of the experiences he treasured most from the half-year or so he had spent in New York.

Having witnessed infighting and further examples of aversive behavior among the New York surrealists, followed by the breakup of the scene at war's end, Lamantia was alienated and disillusioned — and for the moment, ready to renounce surrealism. He boarded a train back to San Francisco in late 1944.

\section{KENNETH REXROTH AND}

THE SAN FRANCISCO RENAISSANCE

In San Francisco, Lamantia enrolled in the Bates School for a year in order to obtain his high school diploma. "But my real education," he stated in his interview with Meltzer, "came from and through the great Rexroth," with whom he renewed his association upon his return from New York. "I saw a great deal of him for a couple of years. Above all, I was attracted by his inexhaustible and encyclopedic way of conversing. I'd visit him once a week. .. . Sometimes we'd talk a whole weekend." ${ }^{20}$ Rexroth's mentorship was a decisive influence, for he provided Lamantia's first serious exposure to the historical depth and geographical breadth of poetry, while encouraging his protégé to pursue religious and political studies. He also afforded Lamantia much practical assistance in obtaining Conscientious Objector status, after turning eighteen in October 1945, in order to register a pacifist refusal to go to war. In terms of his own poetry, Lamantia would frequently refer to this period as his "naturalistic" phase, implying a rejection of the original sources of his inspiration in the unconscious and automatic writing. The poems he wrote at this time comprise the first section of his first book, Erotic Poems (1946), published by George Leite's friend and collaborator Bern Porter, whose eponymous imprint had previously published books by Henry Miller, as well as Parker Tyler's The Granite Butterfly (1945), a poem dedicated to Lamantia. The second half of Erotic Poems contains the earlier surrealist poetry published in View, $V V V$, and elsewhere. ${ }^{21}$ Erotic Poems was introduced by Rexroth, who also suggested its title. In his introduction, Rexroth downplays the distinction between the two sections, and notably, Lamantia would reprint some of the poems from the "naturalistic" section in the first edition of his retrospective gathering of his early surrealist work, Touch of the Marvelous (1966). Generally speaking, the naturalistic poems are more measured in tone and pace than the earlier work, but lines like "You flee into a corridor of stars. / You sleep in a bleeding tree, / And awaken upon the body of trance" suggest that the "naturalism" of this period is highly relative.

In the late I940s, Lamantia was an active participant in the San Francisco Libertarian Circle, a Wednesday-night discussion group that formed around Rexroth, concomitant with his famous Friday-night at-home salons. "Poets associated with the Rexroth circle," as Michael Davidson notes, "included Robert Duncan, Philip Lamantia, Jack Spicer, William Everson, James Broughton, Thomas Parkinson, 
Madeline Gleason, and Richard Moore." ${ }^{22}$ In short, the meetings were the beginning of the pre-Beat-era San Francisco Renaissance, yet they were by no means restricted to poets and artists; Lamantia estimated that the participants eventually numbered over a hundred. ${ }^{23}$ The subject matter of these meetings was as various as Rexroth's protean interests - Lamantia once lectured on the theories of Wilhelm Reich-but appears to have largely focused on philosophical and political anarchism, with participants reading the works of such writers as Peter Kropotkin, Enrico Malatesta, Emma Goldman, Martin Buber, and Nikolai Berdyaev. During this period, along with fellow poets Sanders Russell and Robert Stock, Lamantia also edited a magazine, The Ark, intended as a more politically oriented companion to Circle, though disagreements among the three editors halted its publication after the first issue in spring 1947 .

In addition to these activities, between 1947 and 1949, Lamantia audited a number of classes at the University of California, Berkeley, though he never formally enrolled. While he sat in on poetry lectures by Josephine Miles-mentor to Duncan and Spicer, among others - Lamantia primarily attended classes in comparative religion and medieval history. He was deeply influenced by the lectures of Leonardo Olschki and Ernst Kantorowicz. Olschki taught a course that formed the basis of his later book, Marco Polo's Asia: Introduction to His "Description of the World" Called "Il Milione" (1960). His lecture on "The Assassins" sparked Lamantia's interest in Islam, leading him to study the Koran and retain a lasting sympathy for that religion. Kantorowicz, an expert on medieval political and intellectual history, specialized in Frederick II of Sicily, the thirteenth-century Holy Roman emperor whose religious tolerance, polymath erudition, and patronage of poetry had a lifelong appeal for Lamantia and awakened his interest in his own ethnic heritage. Kantorowicz's 1947 lectures titled "The King's Two Bodies"- the basis of his 1957 book of that namewere attended by Duncan, Spicer, Moore, and Lamantia of the Rexroth group. For a time, Lamantia even roomed in the same Berkeley boardinghouse as Duncan and Spicer, at $2018 \mathrm{McKinley.}^{24}$

It was also in Berkeley that he met the linguist Jaime de Angulo, whose work would inspire Lamantia's investigations into Native American cultures. Mention must also be made here of the eccentric ethnomusicologist, painter, and filmmaker Harry Smith, whom Lamantia met in 1948 and with whom he would further develop his interest in modern jazz and the newly emerging rhythm and blues. In addition to their frequent attendance at small after-hours clubs throughout San Francisco's Fillmore district, as well as downtown Oakland, the two shared a fascination with alchemy, aided and abetted by Smith's knack for obtaining rare alchemical texts. ${ }^{25}$

Apart from Rexroth, Lamantia's most important friendship during this period was with John Hoffman. Born in Menlo Park, California, in 1928, Hoffman was a thin, bespectacled poet with long blond hair and a small beard, the very image of the subsequent "beatnik" stereotype in American culture. He and Lamantia met in San 
Francisco around 1947 after a poetry reading. Hoffman was already familiar with his new friend's poetry, for, when they repaired to Hoffman's cheap hotel to smoke marijuana, Lamantia noted "there were only two books in his room: a bound copy of the poems of St. John of the Cross-a rare book even then-and a copy of my first book, Erotic Poems." ${ }^{26}$ The pair became fast friends, even sharing an apartment together in Berkeley for a time, and Lamantia would later describe their relationship as "the deepest friendship I've ever had with another male in my life." "John was a very religious person," Lamantia recalled, suggesting their mutual interest in the spiritual life was one of the bases of their bond..$^{28}$

\section{BEAT GENERATION}

The appearance of Hoffman might be considered a sign of Lamantia's transition into the "Beat" phase of his life. For whereas Lamantia's precocious rise to avant-garde prominence in the 1940s meant that his first colleagues had often been considerably older, he now began to associate with poets and artists approximately his own age; "the best minds of his generation," as it were, were catching up with him. At the same time, the 1950s would prove to be one of the most difficult periods of his life-one he often referred to as a period of "eclipse" - marked by poetic restlessness, intense spiritual and physical wandering, and drug addiction. ${ }^{29}$ In late 1949 , Hoffman went to New York City, where Lamantia joined him shortly afterward. By the time Lamantia arrived, Hoffman had already begun intravenous use of heroin, and he immediately introduced his friend to the drug. Lamantia would struggle with heroin addiction throughout the 1950s. In New York they also met Jack Kerouac, Allen Ginsberg, and other key figures of the Beat Generation. Indeed, according to Kerouac, aspects of Lamantia and Hoffman are "condensed" into the generalized portrait of junkie squatters in The Subterraneans (1958), while Hoffman is mentioned in William Burroughs's first novel, Junky (1953)..$^{30}$

Lamantia's travels, drug use, rebellious attitude, interest in jazz and spiritual exploration, and friendships with Kerouac, Ginsberg, and others seem to mark him as a Beat poet. Certainly his poetry developed a more vernacular diction during this period. Yet there were notable differences between Lamantia and the Beats. The Beats were in the ascendant, loudly laying claim to their own space within culture, confidant of the authenticity of their own voices. Lamantia, in contrast, was at this time unsure of his identity and direction as a writer. Moreover, Lamantia's focus on esotericism set him apart from the Beats, who were more interested in immediate reality. As Nancy Joyce Peters observed in her biographical essay on Lamantia, "While much Beat writing was spontaneous reportage and meditation on daily life, Lamantia concentrated on hermetic, symbolic, and magical themes." ${ }^{31}$ This observation is echoed by one of Ginsberg's biographers, Bill Morgan, who wrote, "Allen thought that Lamantia's writing was too focused on cabalistic themes. Deep down 
Allen felt Philip was not an ignu (a special honorary term he and Kerouac had coined to apply to like-minded people)." ${ }^{32}$

In 1950, Lamantia made his first trip to Mexico, accompanied by another friend, the poet, avant-garde filmmaker, and editor of Contour, Christopher Maclaine. Very little is known about this particular trip. According to an unpublished interview with John Suiter-used as source material for Suiter's book Poets on the Peaks: Gary Snyder, Philip Whalen \& Jack Kerouac in the North Cascades (2002) - Lamantia had read Antonin Artaud's Voyage to the Land of the Tarahumara (written in 1936, published in 1945) "by 1949," and, though the two poets didn't visit these remote people, it seems likely that Artaud's account of the psychotropic effects of the peyote cactus at least partially motivated their visit. ${ }^{33}$ Whether or not they obtained peyote on this trip, Lamantia soon learned he could order dried peyote buttons through the mail, from various seed catalogs. It's no exaggeration to claim, as Suiter does, that Lamantia introduced peyote into the Bay Area literary scene, over a decade and a half before San Francisco's late '6os psychedelic heyday. ${ }^{34}$ "As early as 1951," Suiter writes in Poets on the Peaks, Lamantia "and a half dozen friends had 'a sort of little Berkeley peyotl cult of our own ... taking peyote weekly for several months." ${ }^{35}$ During this time, Lamantia was living with others in one of two Maybeck-designed houses in the Berkeley Hills owned by Jaime de Angulo's widow, Kathleen Freeman. ${ }^{36}$ The house in which he lived contained de Angulo's library of ethnographic and anthropological books, among them Carl Lumholtz's Unknown Mexico (1902), in which Lamantia read of the three indigenous Mexican peoples with peyote rituals: the Tarahumara, the Huichole, and the Cora.

Also at this house, in early 1952, Lamantia would receive a visit from Kerouac and Neal Cassady, turning them both on to peyote, though Kerouac would famously fall asleep and experience none of the plant's hallucinatory effects. ${ }^{37}$ Still, Kerouac would report on his continuing fascination with Lamantia's poetry, personality, and peyote experiences in a letter to Ginsberg that year, describing the de Angulo house as a "stone small castle overlooking Berkeley Calif." Lamantia, "reclined in a sumptuous couch," was reading the Tibetan Book of the Dead and speaking in arcane terms about his peyote visions. Kerouac wrote Ginsberg that the visit precipitated the first quarrel between himself and Cassady, inasmuch as the latter objected to Lamantia's esoteric behavior and conversation. According to Kerouac, "I was disappointed in Neal that night for not at least digging" what Lamantia had to say. "This made Neal mad, and the next night, for the first time in our lives, we had a fight-he refused to drive me to Lamantia, outright." ${ }^{38}$

That Lamantia and Cassady failed to connect is perhaps unsurprising. The "barbaric yawp" of the Beats exemplified by Cassady contrasted with what many of them, including Kerouac, perceived as Lamantia's hieratic manner. In Kerouac's novel Desolation Angels, Lamantia (as "David D'Angeli") is described "lying elegantly on a white fur cover on a bed, with a black cat, reading the Egyptian Book of the Dead 


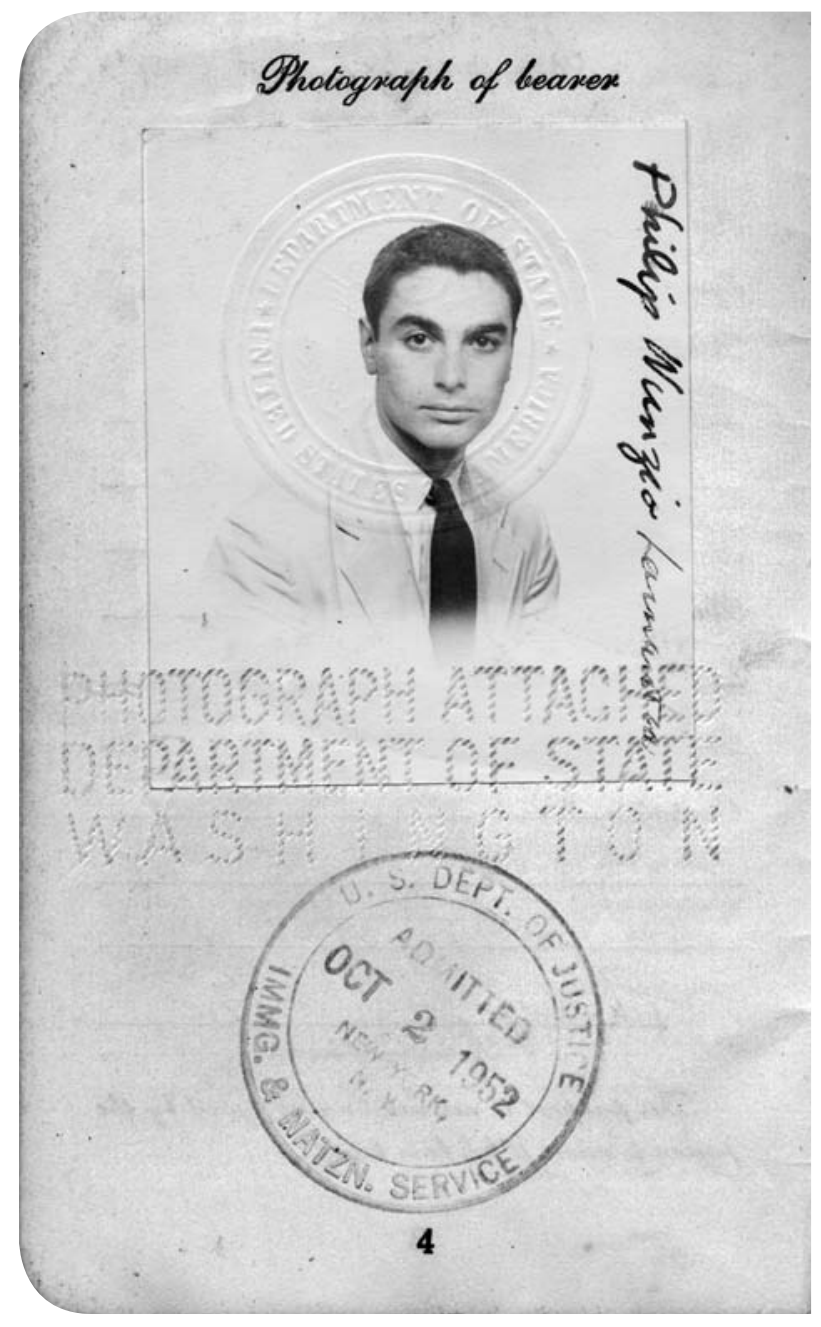

Passport photo, 1952. Courtesy of The Bancroft Library, University of California, Berkeley.

and passing joints around, talking strangely ... holding out his thin white delicate priest-hand to gesture." Kerouac was especially struck by Lamantia's unusual speech pattern: "that accent he talks in I do not know where he picked it up-It's like a Moor educated at Oxford ... it's a distinctly flavored accent made up of (apparently) American Italian second-generation but with strong Britishified overlays upon his Mediterranean elegance, which creates an excellent and strange new form of English I've never heard anywhere." 39

In the summer of ' 52 , Lamantia traveled to Europe for the first time, visiting 
Paris though not making contact with the surrealist group, then on to Morocco, where he lived for six months and renewed his friendship with Paul Bowles. By 1953, Lamantia had returned to San Francisco, taking a room in a neglected mansion on Franklin Street known as the "Ghost House," which also housed Robert Duncan and Jess Collins, Chris Maclaine, and others. In the spring of that year, Lamantia met Goldian "Gogo" Nesbit, a photographer and poet whom he would marry not long afterward. Their relationship heralded one of the most visionary periods of his life, beginning with an "out of body" experience Lamantia had that Allen Ginsberg would later celebrate in line 5 of "Howl": "who bared their brains to Heaven under the El and saw Mohammedan angels staggering on tenement roofs illuminated." ${ }^{\prime 4}$ Although Ginsberg took the poetic license of setting the scene in New York, the actual incident took place in an apartment on Polk Street in San Francisco. Lamantia would later recount the vision for the 1986 annotated edition of Howl:

1953, Spring, aged 25, reading the Koran on a couch, one night I was suddenly physically laid out by a powerful force beyond my volition, which rendered me almost comatose: suddenly, consciousness was contracted to a single point at the top of my head through which I was "siphoned" beyond the room, space and time into another state of awareness that seemed utterly beyond any other state before or since experienced. I floated toward an endless-looking universe of misty, lighted color forms: green, red, blue and silver, which circulated around me accompanied by such bliss that the one dominant thought was: This is it; I never want to return to anywhere but this place-i.e., I wanted to remain in this Ineffable Blissful Realm and explore it forever-since I felt a radiance beyond even further within it and so, suddenly the outline of a benign bearded Face appeared to whom I addressed my desire to remain in this marvel—and who calmly replied: "You can return, after you complete your work." ${ }^{41}$

Ginsberg, who had moved to San Francisco that same year, first heard this story after one of Rexroth's Friday night gatherings, which he had begun to attend with Lamantia. As Morgan writes in his biography of Ginsberg, "After a party at Rexroth's, Allen and Philip Lamantia spent the night in a cafeteria talking about Lamantia's own visions. . . Allen was envious of Philip's mystical experiences, which reminded him of his Harlem epiphanies of nearly a decade earlier." ${ }^{\prime 2}$ This visionlike Ginsberg's epiphanies, unaided by hallucinogens-had a profound impact on Lamantia. During this period he also began writing the poems he would collect as Tau, the only complete but unpublished manuscript found among his papers. In contrast to the baroque quality of Lamantia's radiant vision, the poems of Tau are frequently spare and meditative, seemingly related to his esoteric researches at the time though frequently opaque in regard to their subject matter.

Another manuscript from this period that didn't survive was called Expel the Green Pain, announced in Lamantia's biographical note in James Laughlin's annual New Directions in Prose \& Poetry 14 (1953). This book was to have concerned Lamantia's experiences on peyote, and it's unclear whether he retained any of these 
poems. In any case, his most significant peyote adventure was yet to come, for in 1954 , accompanied by his wife and George Leite, who arranged the visit, Lamantia went to Woodfords, California, to participate in the Washoe Indians' peyote ceremony. This ceremony took place at night in a large tipi, specifically erected for this purpose, with "about forty or fifty people" seated in a circle around a fire, accompanied by drumming and singing. ${ }^{43}$ The content of Lamantia's peyote-induced visions hasn't been recorded, beyond such synesthetic statements as "The sky tasted like crystal star meat" in an unpublished notebook "memorial" of the event, but it seems clear that the ritual helped foster his attraction to communal religious experience.

Later in 1954, Lamantia and Nesbit moved to Mexico, where he would live for extended periods over the next several years. He immersed himself in its history and cultures, and formed friendships with surrealist painter Leonora Carrington and poets Homero Aridjis and Ernesto Cardenal. Lamantia was drawn to the distinctly baroque character of Mexican Catholicism, with its marvelous churches and its idiosyncratic iconography, rites, and penances. His solitary visions continued, including what he described as a thirty-second "Christic" revelation later that year. Yet the increasing intensity of Lamantia's mysticism appears to have put a strain on his marriage, and in early 1955, the couple would split up; Goldian became involved with a friend of theirs in Mexico City, André VandenBroeck, whom she would later marry, while Lamantia set out on a perilous journey to visit the Cora Indians, about whom he'd read in Unknown Mexico and who lived in Sierra Madre mountains of Nayarit.

Although he stayed with the Cora Indians for two months, Lamantia never took peyote with them; as he told John Suiter, there were "something like thirty secret rituals in the course of a year . . . but I was there in early spring, and the peyote rite didn't come on until Easter." ${ }^{\prime 4}$ Instead it was the season for yahnah, an extremely potent black tobacco the Cora cultivated whose effects Lamantia described as "narcotic." The yahnah ceremony took place at night in a Jesuit missionary church, as did a Cora funeral he witnessed on first arriving. What struck him forcefully was that the Cora's indigenous beliefs and Catholic practice existed side by side in this remote mountain village, and seemed equally real embodiments of the human aspiration to union with the Divine. This insight was amplified by another incident occurring prior to the yahnah ceremony, when Lamantia was stung by a scorpion and nearly died; in his pain, he spontaneously cried out to the "Madonna" - that is, the Blessed Virgin Mary-to save his life. The combination of these events led to Lamantia's subsequent fervent embrace of the religion into which he was born; this had serious implications for his poetry, as he began to view his preconversion writings as blasphemous.

\section{SIX GALLERY}

In 1953, when the owner of San Francisco's Six Gallery, an old garage that had been converted into an art gallery and performance space, offered to host a group reading, 
Kenneth Rexroth and Allen Ginsberg drew up a list of five younger poets-Ginsberg himself, Lamantia, Gary Snyder, Michael McClure, and Philip Whalen-whom they considered most representative of the new, antiestablishment poetics at that time. Rexroth would act as master of ceremonies. Ginsberg also wanted to include Kerouac on the bill; at Ginsberg's urging, Kerouac returned from Mexico to participate in the event, but subsequently declined to read.

Lamantia also was reluctant to present his own work at the Six Gallery reading. His engagement with Catholicism reached its greatest intensity in 1955, just around the time of the reading. As Lamantia recalled in an interview, "I was going through a crisis of conversion and I couldn't write and I didn't want to read my old poems-I didn't want to publish my old poems, I ceased to publish, I wanted to withdraw." ${ }^{35}$ Lamantia had, in fact, withdrawn, six months before the reading, to a Trappist monastery in Oregon for a retreat, and had also pulled the manuscript of his poem-cycle Tau from the publisher Bern Porter just as the book was about to go into production. ${ }^{46}$ At the persistent urging of Rexroth and Ginsberg, Lamantia finally agreed to read, not from his own work, but from that of his friend John Hoffman, whose death in 1952 under mysterious circumstances in Mexico affected Lamantia greatly. A collection of Hoffman's poems, Journey to the End, was scheduled for publication by Bern Porter around the same time as Porter was to have published Lamantia's Tau. This reading would be a memorial tribute to his friend.

The Six Gallery reading took place on October 7, 1955, before a large and enthusiastic crowd. Lamantia was first to read, and made his entrance, according to Kerouac's mildly fictionalized account in The Dharma Bums, looking like "a young priest." As Kerouac noted, it was "the night of the birth of the San Francisco Poetry Renaissance.... It was a great night. Delicate Francis DaPavia [Philip Lamantia] read, from delicate onionskin yellow pages, or pink, which he kept flipping carefully with long white fingers, the poems of his dead chum Altman [Hoffman] ... and read them in a delicate Englishy voice that had me crying inside with laughter though I later got to know Francis and liked him. ${ }^{{ }^{3} 7}$ According to Michael McClure, Lamantia's reading of Hoffman's "beautiful prose poems ... left orange stripes and colored visions in the air." ${ }^{38}$ As is well known, the pivotal moment of the event occurred when Ginsberg read from his long poem "Howl." The founder of City Lights Books, Lawrence Ferlinghetti, was in the audience and was moved, upon hearing "Howl," to offer Ginsberg a book contract. Yet, after the Six Gallery reading, when, in Kerouac's words, "all the poems were read and everybody was milling around wondering what had happened and what would come next in American poetry," Hoffman's poems slipped from sight and would not be published until the next century, when Hoffman's Journey to the End and Lamantia's Tau were issued in the same volume by City Lights (2008).

Of all the younger poets on the bill, Lamantia was the best known at that time; 
the others had yet to publish their first books. There is some irony in this, for the other Six Gallery readers would, in less than a decade, achieve much wider recognition than Lamantia. When the reading was restaged five months later in Berkeleymostly for the benefit of the media-Lamantia was the only member of the original lineup who did not participate, having returned for another visit to the Trappist monastery in Oregon. For the next few years, Lamantia's fervent Catholic devotion seemed to inhibit his poetic practice, or, at least, his confidence in its results. Perhaps surprisingly - in view of his amusement at the more baroque features of Lamantia's persona-one of Lamantia's closest friends during this period was Jack Kerouac. Immediately following the Six Gallery reading, Kerouac and Lamantia stayed a few weeks at Lamantia's mother's home in San Francisco, where the two resumed their ongoing dialogue on comparative religion. ${ }^{49}$ Kerouac had been looking beyond the doctrines of his own French-American Catholicism-which prioritized the culpability of the individual ego in relation to God-toward the "ego-less" doctrines of Buddhism that, by defining suffering as merely an illusion of the ego, seemed to offer greater consolation, while Lamantia pointed out the inherent "emptiness" and "negativity" of Buddhism and tried to lead Kerouac back to the Catholic faith. As Kerouac confessed in Desolation Angels, Lamantia "really dented my brain with his enthusiastic, passionate and brilliant expositions of the Universal Orthodoxy." 50 Recalling these discussions many years later, Lamantia said that he believed Kerouac "in his heart had remained a Catholic, all right." ${ }^{1}$ Nonetheless, Lamantia credited his friendship with Kerouac, as a Catholic whose faith accommodated an enthusiastic interest in and practice of various tenets of Buddhism, with helping him relax his quite possibly self-destructive level of rigor in the immediate aftermath of his first conversion.

In the three years that followed the Six Gallery reading, Lamantia frequently went on the road-partly as an attempt to stave off the cycles of depression that plagued him - traveling between Mexico and New York in hope of finding sources of ecstatic experience. In New York in late 1957, he reunited with Kerouac, and the two joined forces with the Beat poet Howard Hart and David Amram, a composer and pioneer jazz French horn player, to stage what has been recognized as the "first jazz-poetry reading" at the Brata Art Gallery in Greenwich Village, followed by performances at Circle in the Square. ${ }^{52}$ It is likely that Lamantia read passages from Tau at these events in the Village. The manuscript of Tau that has been preserved among Lamantia's papers is marked with musical notations that may have been intended as performance cues. The fact that Lamantia chose to read poems from Tau in New York, after suppressing these poems at the Six Gallery reading three years earlier in San Francisco, gives some indication that he was relaxing-undoubtedly with Kerouac's encouragement-the strictures that he had imposed on himself at the height of his "fervent" Catholicism. 


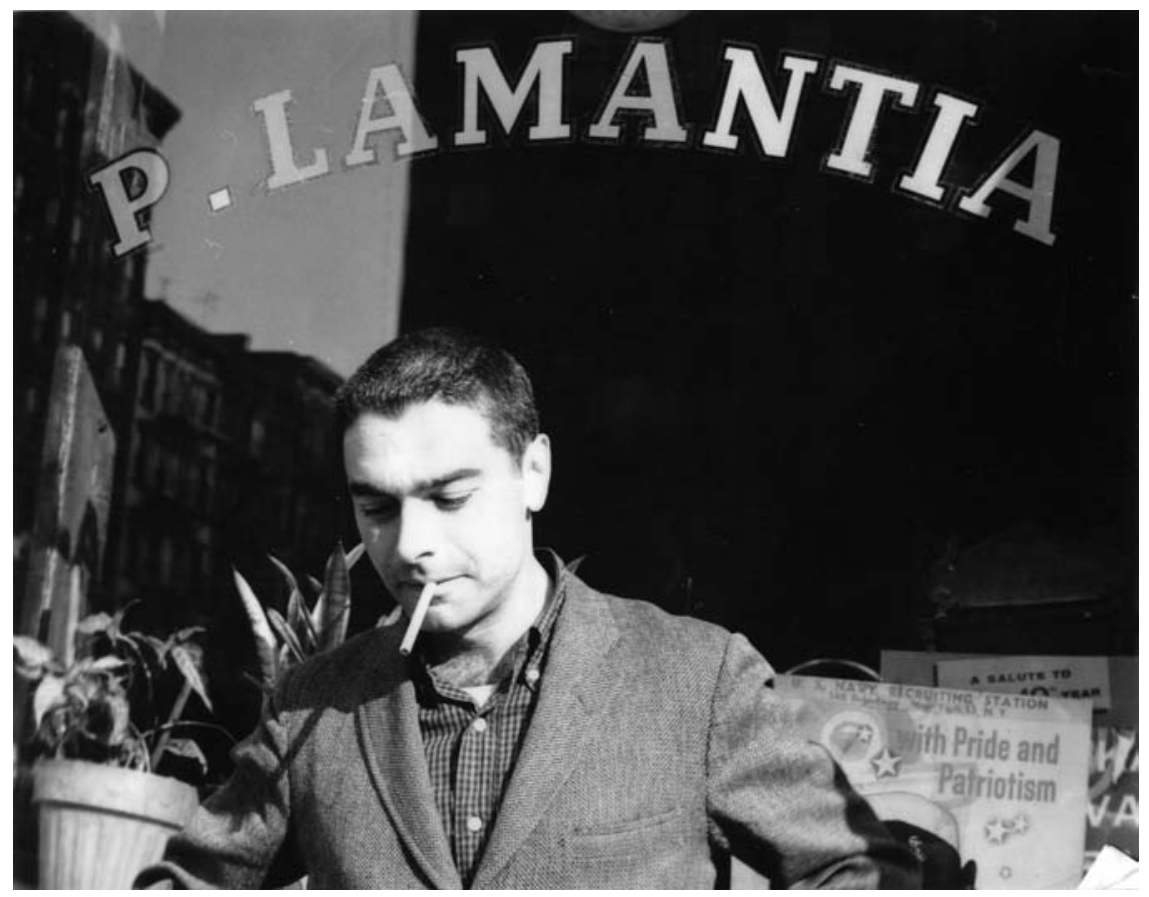

New York City, 1950s. Courtesy of The Bancroft Library, University of California, Berkeley.

During this period of jazz and mysticism, Lamantia had one of his more singular experiences as a "spokesperson" for the Beat Generation when he and Kerouac were each interviewed by TV personality Mike Wallace for his daily column in the New York Post. After quoting the last section of Lamantia's poem "Binoculars”-“COME / HOLY GHOST / for we can rise / out / of this jazz"-Wallace questions Lamantia on the connection between jazz and God. Lamantia answers, "throughout the ages, mankind has been searching for some kind of ecstasy, some marvelous vision of God, you know. That's why we smoke marijuana, or listen to jive. It's all just a way to ecstasy." 53 Time magazine would publish a rather flip encapsulation of the two interviews under the heading "Beat Mystics," accompanied by fragmentary excerpts, two weeks later. ${ }^{54}$ But this was mild compared to the treatment they would receive the following year in Life magazine's Beat Generation attack piece, “The Only Rebellion Around,” which also offers caustic appraisals of Ginsberg, Corso, McClure, Burroughs, Ferlinghetti, and Bob Kaufman. Under the heading "A Fix at the Altar," Lamantia is derided as "a Catholic and impassioned student of theology who has convinced himself that the use of drugs to obtain visions does not conflict with the canons of the Church." 55 Ironically, it seems that Lamantia's religious belief most offends Life's conformist critique of the Beat Generation. 
By 1958, Lamantia had returned to Mexico City, where he met Lucile Dejardin-a Frenchwoman working in the theater as a costume designer-whom he would marry two years later. Not much is known of this marriage, as Lamantia seldom spoke of it after it ended in divorce in 1964. The fact that, as two Roman Catholics, their marriage was not merely civil but sacramental exacerbated his sense of failure when their relationship ended. ${ }^{56}$ Manic depression also contributed to the breakup; when they met, Lamantia was in a stable phase of his cycle, and Dejardin was understandably unprepared for the intense manic episodes when they inevitably returned. The separations and reunions that occurred throughout their relationship were compounded, moreover, by legal difficulties, for Lamantia was expelled from Mexico in 1959 due to his association with a known drug dealer, and was subsequently arrested on his arrival in Texas, spending approximately two months in jail. ${ }^{57} \mathrm{He}$ reentered Mexico illegally in 1961, and soon after had one of his most elaborate visionary experiences, when he and the painter Aymon de Sales were driven off the Pyramid of the Sun at Teotihuacan by "hundreds" of "Black Shapes" that the two considered to be "demons." ${ }^{\text {" }}$ His presence in Mexico came to the attention of governmental authorities, however, and he was deported again in 1962 , losing many valuable papers in the process, including the letter he had received from André Breton back in 1943.

Nonetheless, the period was a productive one for Lamantia, at least in terms of publishing. In 1959, some thirteen years after Erotic Poems, he finally published a second book of poems, Ekstasis, with Dave Haselwood's Auerhahn Press. A member of the Wichita Beat vortex that produced Bruce Conner and Michael McClure, Haselwood would publish some of the most significant books of this period of San Francisco poetry, including John Wiener's The Hotel Wentley Poems (1958), McClure's Hymns to St. Geryon (1959), Philip Whalen's Memoirs of an Interglacial Age (1960), and Jack Spicer's The Heads of the Town up to the Aether (1962), among many others. According to its brief prefatory note, Ekstasis contains poems written between 1948 and 1958, presented in reverse chronological order. ${ }^{59}$ Much of Ekstasis is religious in nature, such as the prayer "Ah Blessed Virgin Mary" or the hermetic lyric "Mysterium Mysticus Ecclesia." Influenced by his reading of Welsh metaphysical poet and priest George Herbert (1593-1633), Lamantia also expressed his devotion through concrete or "pattern" poems: "Christ" (in the shape of a cross), "In a grove" (a vortex and triangle), and "What gift to bring" (a cross-topped dome). Three poems from the Tau manuscript"Man is in pain," "Terror Conduction," and "Intersection"-appear in Ekstasis, indicating he had come to terms with them, and even a few earlier preconversion poems, after their initial suppression. Moreover, the book's third and thus comparatively recent poem, "Interior Suck of the Night," has no overtly religious theme, but rather concerns a visionary experience smoking opium. This poem most explicitly links the mysticism of Ekstasis to the other Lamantia title issued by Auerhahn that year, Narcotica. 
Announced in Ekstasis under its original title, A Demand for Extinction of Laws Probibiting Narcotic Drugs, Narcotica is at once Lamantia's most notorious and iconic publication and the one toward which he felt the most ambivalence. Its notoriety partly stems from its cover photographs, by Semina creator Wallace Berman, depicting Lamantia shooting up. As Lamantia told it, he didn't authorize the appearance of these photos, claiming the cover was to be all text; indeed, the pamphlet-sized book seems to have two covers, the photographic wrap with four images of Lamantia, and a sheet of red cardstock with a variant of the original title, I Demand Extinction of Laws Probibiting Narcotic Drugs, printed in pyramid form. Lamantia was dismayed by the images for reasons both personal — not wanting his family to see and fearing the very real possibility of arrest-and philosophical, for he felt they sensationalized the text, undermining the seriousness of its purpose. Notably he would never reprint any of Narcotica, his misgivings compounded by the feeling the text was no longer "accurate" in terms of the evolving political discourse around drugs in the United States.

A hybrid text, Narcotica consists of four poems by Lamantia, his translation of a poem by Giocomo Leopardi, and the prose "Demand" of its alternate title, plus two texts by Artaud concerning opium, translated by Lucile Dejardin. While his enduring anarchist political orientation is evident throughout the text-particularly in his assertion that "It is I WHO AM THE LAW!"-Lamantia felt Narcotica was misinterpreted, writing in an undated typewritten note: "any creep who got the impression I was recommending the taking of narcotics—addictive or not-doesn't understand THE NATURAL RIGHT OF THE POET TO SPEAK TRUTH AS HE SEES IT." Much of Narcotica, including Artaud's two texts, "A Letter to the Legislator of the Law on Narcotics" and "General Security-The Liquidation of Opium," concerns the psychic pain motivating drug addiction, which, in Lamantia's case, was rooted in his still-undiagnosed manic depression. While it has ecstatic moments - notably the ode to hashish, "Memoria"-generally speaking, Narcotica is concerned with the political and psychiatric aspects of illegal drugs, while moments of ekstasis are reserved for the book of that title, hence the inclusion of "Interior Suck of the Night" there. The division between Ekstasis and Narcotica, in other words, isn't between religious and drug experience but rather between mystical and political experience.

Of particular note in Lamantia's Auerhahn period is the emergence of a concept he christens "weir." This is not to be confused with the contemporary English word "weir," a type of dam, but instead is a variant on the word "weird" that Lamantia derived from his researches into Anglo-Saxon. Perhaps the most widely read elaboration of the concept comes not from Lamantia but rather from Michael McClure, whom Philip had known since the mid-I95os but who became a close friend around this time. In "Phi Upsilon Kappa," the first essay in the second edition of his book Meat Science Essays (1963, 1966), McClure cites Lamantia’s concept as he describes the 
visionary state induced by peyote: "Philip Lamantia and I had spoken many times. He had mentioned his concept of Weir to me. Now I knew the phenomena I had seen with my still peyoted eyes - the chill luminescence-and the aelf-scin of the Anglo Saxons were the same radiance and halo. I saw that the aelf-scin was much the same light illuminating what Philip called Weir. Weir is a solid spectral reality of light on particular objects in special moments of vision." ${ }^{60}$ To this we might add Lamantia's own dictionary-style definition, drawn from an ambitious, heavily worked, but ultimately abandoned text, "Weir-o-Rama”: "weir: anglosaxon: 'weird,' from Latin \& Greek: TO SEE in a certain 'light.'” This too suggests the visionary state, and while clearly engendered by Lamantia's experiences with hallucinogens-in a handwritten poem of the early '6os, he will write: "My land of Weir, that is, sight of LSD light"-weir would seem to be an attempt to correlate his experiences of mystical, drug-induced, and poetic vision under one heading. This is a singular instance in his poetics, for Lamantia was by nature a seeker, researching a wide variety of extant knowledge, rather than a synthesizer or developer of original concepts. There's some indication he found this task uncongenial, given his inability to complete "Weir-oRama" and the existence of several unpublished poems relating to weir. Nonetheless, the concept persists in Lamantia's work for nearly a decade, beginning with the word's appearance in Ekstasis (in "Fragments from an Aeroplane" and "Ball") and Narcotica (in "Opium Cocaine Hemp") through its final manifestation in "Gork!" in his 1967 Selected Poems.

But the weir concept probably exerts its greatest influence on Lamantia's third Auerhahn title, Destroyed Works (1962), which ends with the following "Note on DESTROYED WORKS and later": 61

For me it is the Vision in its density and the truth of what I see the breath is in the Vision and I come to the rhythms it is above all a question of MY VISION thru which the images are focused, the beat in the activation of this energy field, hence the density, that the Being of poetry erupts out of nerves emotions skeleton muscles tongues eyes spirits beasts birds rockets typewriters into my head and I see, the weir pivot, at that point all is Evidence Clarity Incomprehension Flame of Perfect Form and Chaos.

October 20, 1960

From this statement, it isn't difficult to see weir as a conceptual bridge out of Lamantia's Catholic phase and back to surrealism, for weir has gone beyond passive experience of "the Vision" to become a poetic practice-an eruption-not unlike surrealist automatism. Indeed, despite his disavowal at the time, surrealism continued to exert its influence on Lamantia, manifested through his inclusion of a dissident surrealist like Artaud in Narcotica or by his remark in Ekstasis that "Christ IS the marvellous," prefiguring his surrealist Catholic period of the late' 90 . Notably, in any case, 
the concept of weir will disappear not long after he formally returns to surrealism in 1965 .

The title of Destroyed Works refers to one of the signal events of Lamantia's artistic life: the burning of most of the poetry he'd written but not published since Erotic Poems. The exact circumstances and sequence of events around this act aren't fully known, but it was a deliberate, premeditated renunciation of his life as a poet, a continuation and amplification of the spiritual crisis begun on his conversion and compelling him to suppress his own work at the Six Gallery reading. The immediate catalyst may have been a deep depression over the deterioration of his relationship with Lucile, aggravated by his deportation and arrest. Prior to destroying these poems, however, Lamantia created a twenty-five-page typescript titled "Destroyed Works," made up of forty-one numbered sections; these sections contain fragments from longer works as well as some complete poems, such as number 36 , "Cora," about his experiences with the tribe, and number 38 , "Sphinx or Cat," dedicated to Leonora Carrington, whom he'd first met in Mexico in 1954. That the contents of this typescript go back at least as far as the beginning of the 'sos is evident from number 5 , a variant of which was recorded by John Hoffman in one of his notebooks and credited as "Philip Lamantia, 1950." 22 The quantity of work Lamantia destroyed is unknown, and he didn't destroy everything, as evidenced by the survival of the Tau manuscript and other stray poems. Nonetheless, almost nothing from the late 1940 s appears to survive, while most of the remaining poems from the 1950 s tend to be from late in the decade.

Oddly enough, nothing from the "Destroyed Works" typescript appears in Destroyed Works. Judging from both stylistic and internal evidence, moreover, the majority of Destroyed Works consists of poems written between 1958 and 1960, thus making its contents roughly contemporary with its publication. ${ }^{63}$ The title refers to the event itself, in other words, rather than the actual poems in the book. Lamantia seemingly used the "Destroyed Work" typescript as a model—using bullet points rather than numbers to separate the various poems-but filling this structure with more recent content. Unlike the typescript, the book is divided into four suites of poems: "Hypodermic Light," "Mantic Notebook," "Still Poems," and "Spansule." Stylistically, Destroyed Works grows out of the manic denunciations of Narcotica, continuing that volume's emphatic use of capital letters and tending toward long lines and prose poems. While the Catholic content of Ekstasis remains, its quiet, reverential tone has disappeared in favor of fervent but unorthodox pronouncements like "Christ is a rocket ship." ${ }^{64}$ Notably, the book's cover is a photograph of Bruce Conner's assemblage "Superhuman Devotion," which itself had been destroyed by the time the book was printed. Conner and Lamantia met as early as 1955 in San Francisco and continued their friendship in Mexico City, when Conner moved there in the early i960s.

Lamantia's second deportation from Mexico, in 1962, effectively put an end to his 


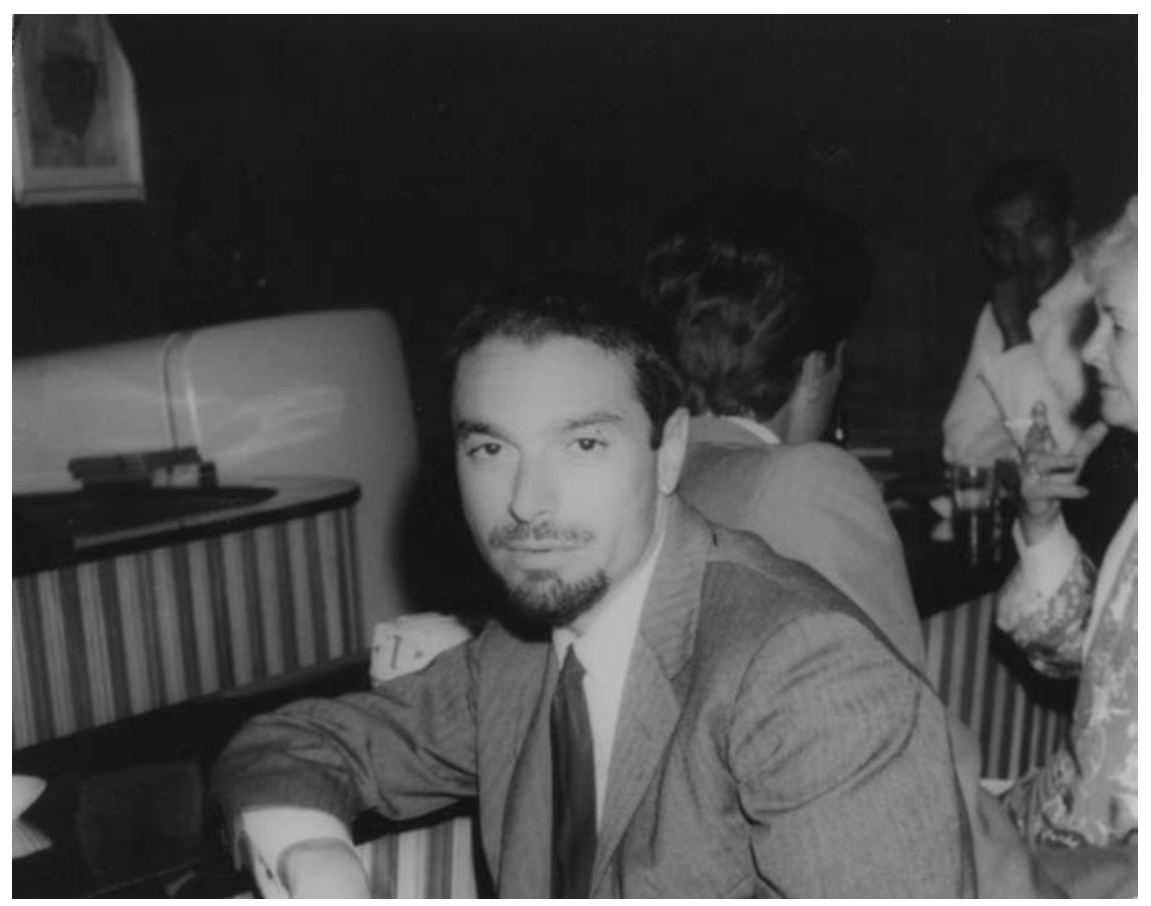

Tangiers, Morocco, 1964. Courtesy of The Bancroft Library, University of California, Berkeley.

relationship with Lucile, who would initiate divorce proceedings the following year. It also seemingly coincided with Lamantia's leaving the Catholic Church, though exactly when this occurred is unknown. His intention to renounce poetry remained, yet though he withdrew from publishing, he never seems to have entirely stopped writing. At the invitation of his ex-wife Goldian Nesbit, Lamantia decided to relocate to Nerja, Spain, where she and André VandenBroeck were living. Since they had left Mexico, VandenBroeck and Nesbit had fallen under the influence of the "sacred science" of Egyptologist R. A. Schwaller de Lubicz, whose chief work, Le Temple de l'homme (1958), was an exigesis of ancient Egyptian philosophy, mathematics, and science as embodied in the symbology of the Temple of Luxor. Through VandenBroeck, Lamantia hoped to gain an understanding of "sacred geometry," conceiving that he would thenceforth devote himself to philosophy instead of poetry.

Before undertaking such a journey, however, Lamantia needed to break his heroin addiction, having fallen into a period of heavy use in the wake of his failed marriage. He accomplished this in late 1962 in Newton, Massachusetts, through LSD therapy guided by Timothy Leary, whose early research into hallucinogens included their use in the treatment of alcoholism. "Phil Lamantia was up for a week," Leary wrote 
to Allen Ginsberg. "He's going through a death-rebirth sequence. Painful but he's great." ${ }^{\text {"5 }}$ Following this cure, Lamantia left for Europe, arriving in Nerja, Spain, in February 1963 and renting a small house down the street from the VandenBroecks. Lamantia would remain there for six months, studying Schwaller de Lubicz with VandenBroeck, but he found himself more interested in Egyptian myth and symbol than in sacred geometry. Lamantia grew frustrated, moreover, with VandenBroeck, whose initial enthusiasm had waned somewhat, though he would later write both a study, Philosophical Geometry (1972), and a memoir, Al-Kemi: Occult, Political, and Private Aspects of R. A. Schwaller de Lubicz (1987), as well as translate, with Nesbit, Schwaller de Lubicz's own writings. In any case, the VandenBroecks went to the Aurobindo ashram in Pondicherry, and by July 1963, Lamantia had resumed his travels in Europe, including a period in Italy, before arriving in Tangiers, Morocco in 1964, where he studied music with his old friend Paul Bowles. At the end of May of that year, however, he was arrested for possession of kif and imprisoned for five days, before being deported from the country.

\section{RETURN TO SURREALISM}

Lamantia's return to surrealism coincided with a reawakening of his poetic powers after three years of silence, a period which he later described as his "season in hell." 66 Certainly, he had always drawn upon his surrealist roots, writing under the sign of a transgressive and transformative imagination. Nonetheless, he had distanced himself from the movement since the late forties; and when he was in Paris in the fifties, he had not bothered to seek out members of the surrealist circle there. By 1960, after an often tortuous itinerary through the cultural landscape of the post-World War II era, Lamantia may have felt that if, as he had phrased it in the title of one of his earliest poems, "There Are Many Pathways to the Garden," he now had no sense of where his next path would take him.

After he left Morocco, Lamantia went to Athens, where he made contact with the circle of the Greek surrealist poet Nanos Valaoritis and American surrealist artist Marie Wilson. Their circle served at that time as a way station for European and American youths and intellectuals going on the road to seek enlightenment in the Middle East and India. Here, Lamantia encountered a number of past acquaintances, including Charles Henri Ford and Harold Norse. And it was here, as a result of the stimulus of this scene, and also of the fact the he was beginning to emerge from a cycle of depression, that Lamantia composed the first poem that pleased him, at least a little, since his renunciation of poetry three years earlier. ${ }^{67}$ The poem was entitled "Blue Grace," an exuberant hymn to the "resurrection" of his "muse" in the guise of the "prophetess," Blue Grace.

It was also in Athens a few months later that Lamantia met the American poet Nancy Joyce Peters - a woman who appeared to him as the very embodiment of his 
muse. Peters had just arrived in Athens from a sojourn in Egypt. Not only was she a participant in the Valaoritis-Wilson scene but she happened to be staying in the same hotel as Lamantia: their courtship began when Lamantia sent her a note, asking her to tell him everything she knew about the moon. ${ }^{68}$ Falling in love, the pair left Athens to visit the site of the Delphic oracle. Their travels took them to the Greek islands and Crete and eventually to Paris; here, Lamantia reunited briefly with Lawrence Ferlinghetti, who was reading at the International Festival of Free Expression. This meeting was not without consequence: later that year, Ferlinghetti would offer to publish a volume of Lamantia's poetry in the City Lights Pocket Poets Series. For the time being, Lamantia and Peters left France and, after a stay in Segovia, settled on the southern coast of Spain, residing a year in Málaga and then in Nerja, the fishing village where Lamantia had lived near the VandenBroecks.

In Spain, Lamantia resumed his study of Egyptian architecture and symbols with Peters, utilizing Peters's knowledge of French to make reading translations of Schwaller de Lubicz's writings. They made new friends, traveled throughout Andalusia, enjoyed gypsy juergas, and spent time in Alhaurín el Grande, visiting Gerald Brenan, whose books on the Spanish Civil War and on Spanish literature Lamantia had admired. Now in a relaxed and joyous relationship with Peters, Lamantia began writing poetry again in earnest. As the title of his first collection, Erotic Poems, indicates, Lamantia had always derived poetic inspiration from the power of Eros; in Málaga, he composed a series of poems—notably, "She Speaks the Morning's Filigree" - giving evidence of Peters's restorative effect on his imagination. Peters was impressed with all of Lamantia's work, but especially charmed by his early surrealist poems, with their fresh vision and imaginative freedom. Recognizing that Lamantia was attempting to overcome his poetic self-destruction, she encouraged him to reconnect with the forces that had sustained his first flowering as a surrealist poet.

Peters, it turned out, was not alone in favoring Lamantia's early work: Oyez Press and City Lights almost simultaneously contacted Lamantia in Málaga, each offering to publish a collection of poems from his surrealist period. Both presses stood at the forefront of the burgeoning literary scene in the San Francisco Bay Area; while City Lights was well established, Robert Hawley's Oyez Press had just begun to attract notice with a small list of finely printed titles by innovative poets. In consultation with Peters-who now acted as both Lamantia's muse and his literary adviser, a role she would continue to fill for the rest of his life-Lamantia decided to give Oyez the collected poems of his first surrealist phase, and to turn the City Lights book into a selected poems volume covering his entire career up to that point.

Thus, there was some overlap between the contents of the Oyez book, which was entitled Touch of the Marvelous and released in 1966, and the first section"Revelations of a Surreal Youth" - of the Selected Poems from City Lights, released in 1967 as Pocket Poets Number Twenty. The second section of the Selected Poems- 
"Trance Ports"-represented the poems of his Catholic/Beat phase; and the final section- "Secret Freedom"-contained new poems representing his return to surrealism. Lamantia's Selected Poems therefore described not a circle, but a Hegelian spiral: a return to the point of origin, but at a higher level. On the back cover, supportive comments were provided by Parker Tyler, associate of Lamantia's first surrealist phase, as well as by Allen Ginsberg, associate of Lamantia's "transitional" period; also included was Lamantia's own declaration: "I'm returning to my initial sources-like an act of nature." ${ }^{99}$

Lamantia's return to these roots was motivated, no doubt, by subjective processes, but it occurred within the context of an objective sociocultural shift at the beginning of the sixties - a shift that resulted in a worldwide renewal of surrealist thought and practice. The French surrealist José Pierre periodized the fortunes of surrealism during the fifties and sixties as follows: "The Traversal of the Desert," I952-58; "The Resurgence," 1959-65; and "The Hour of the Phoenix," 1966-69. ${ }^{70}$ These periods roughly correlate with Lamantia's self-described "eclipse" during the fifties and his own surrealist resurgence in the sixties. ${ }^{71}$ Thus, the two books announcing Lamantia's return to surrealism appeared as part of a rising wave of interest in surrealism in the United States and elsewhere.

Prominent among the new magazines and presses explicitly devoted to surrealism were the publications of the Chicago Surrealist Group, organized by Franklin and Penelope Rosemont in 1966. The Rosemonts had traveled to Paris in 1965 to meet with André Breton and others in the Paris group. Breton welcomed them into the movement; shortly thereafter, the Rosemonts launched an ambitious publishing program that brought many of the seminal works of French surrealism into English translation for the first time. ${ }^{72}$

Certainly, the upwelling of oppositional activity in the sixties promoted a "return to surrealism" within the larger culture. The Situationists and other radical groups explicitly cited surrealism; its influence seemed to expand in proportion to the intensity of the struggle against imperialist war and the one-dimensionality of capitalist society (the slogans of the May '68 revolt in Paris, such as "L'imagination prend le pouvoir," "Je prends mes désirs pour des réalités car je crois à la réalité de mes désirs," "Explorons le hasard," recall passages from the surrealist manifestos). The mystical, apocalyptic, and psychedelic tendencies of sixties counterculture also mingled with political currents, adding momentum to the surrealist surge. By the end of the sixties, surrealist groups and publications were flourishing not only in Western Europe and the United States, but in Eastern Europe and Latin America as well. There was some cause to celebrate the phoenix-like rebirth of surrealism, even at the hour of Breton's death (which occurred in 1966).

The reawakening of interest in surrealism also provided a wider context for the reception of Lamantia's work; by the end of the decade, his Selected Poems from City Lights had sold fifteen thousand copies. In the wake of its publication, Lamantia and 
Peters decided to return to the United States to live. She relocated to Seattle in 1967 to earn a degree in library science from the University of Washington; Lamantia joined her there the following year, taking a steamer across the Atlantic and then a train across the Canadian Rockies. On the steamer, Lamantia wrote a prose poem, "The Romantic Movement" dedicated to Peters, looking forward to their reunion ("The boat tilts on your image on the waves...") and invoking "Chief Seattle's lost medicine pouch." In Seattle, Lamantia and Peters lived together for six months while Peters finished her degree; Lamantia wrote some of the poems that would form part of his next book, The Blood of the Air.

Upon graduation, Peters was offered an excellent position as a librarian at the Library of Congress in Washington, D.C., and Lamantia returned to San Francisco. By that time, San Francisco had become a mecca for the youth movement, which had massively infused fresh energy into the city's long-standing-but marginalcountercultural tradition. Alternative lifestyles, radical politics, and experimental music and art were flowering madly_no longer, as in the fifties, on the margins, but in almost every aspect of the city's life. After spending the better part of a decade away from his hometown, Lamantia was returning to a different San Francisco. He found a inexpensive apartment at 30 Genoa Place in North Beach. Besides reconnecting with family and friends, he began to associate with a number of the young, self-styled surrealists now active in the city, and collaborated in the production of the tabloid-sized magazines, Octopus Typewriter and Anti-Narcissus.

Similar small surrealist groups were arising at many points throughout the United States at this time; in 1970, an effort was undertaken by the largest of them, the Chicago Surrealist Group, to organize their activity at a national level. The resultant organization would be called the "Surrealist Movement in the United States." In keeping with the revolutionary ferment of the period, the movement circulated fiery manifestos and staged political protests and happenings that incorporated art and dance. Its main vehicle was the anthology series entitled Arsenal: Surrealist Subversion, issued by the Chicago Group itself. ${ }^{73} \mathrm{After}$ seeing the first volume (whose format and typography was modeled on French surrealist periodicals of the thirties), Lamantia decided to make common cause with the group. Indeed, Lamantia was eventually recruited to serve on the editorial board of Arsenal; its subsequent three volumes featured not only his poetry but also some of his most important prose statements and essays. ${ }^{74}$

In the same year that the Surrealist Movement in the United States was launched, Lamantia's first all-new collection of poems following his return to surrealism, The Blood of the Air, was published in San Francisco by Donald Allen's Four Seasons Foundation. ${ }^{75}$ To make no mistake about the author's surrealist orientation, an extensive quote from André Breton was placed at the beginning of the book; in addition, a frontispiece drawing was provided by Marie Wilson. ${ }^{76}$ The collection-dedicated to Nancy Joyce Peters, "at the secrets / of the marvelous"-opens with "I Touch You," 


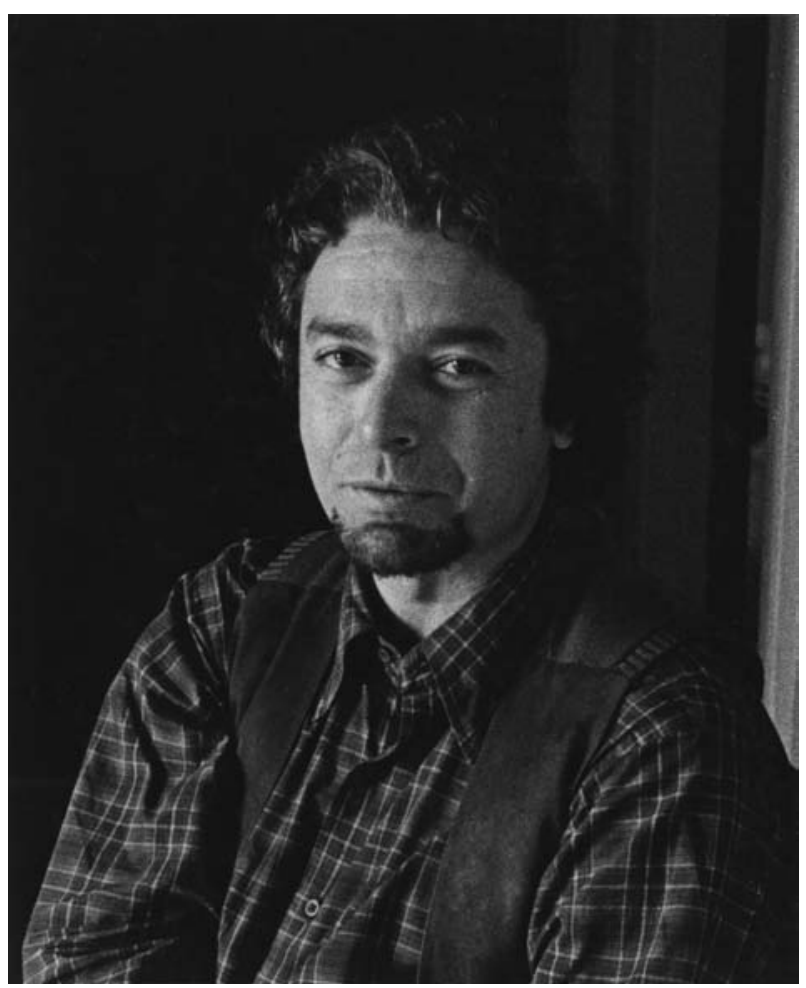

At home in San Francisco, 1970. Photo by Nancy Joyce Peters. Courtesy of The Bancroft Library, University of California, Berkeley.

perhaps Lamantia's most ardent love poem. Despite its brevity, the book as a whole projects-in contrast to the work of Lamantia's earlier, self-destructive phase-a sense of self-confidence, a reclamation of poetic powers, with the poet-magus once more in command of "the coiled element, the supreme root of fire."

In 1971, Peters moved permanently to San Francisco to look for a position as a librarian, after she and Lamantia decided that San Francisco suited them better than D.C. Peters worked briefly for editor and publisher Donald Allen, who was then editing Frank O'Hara's Collected Poems for Knopf; not long after, she joined Ferlinghetti at the editorial offices of City Lights. (Peters would remain at City Lights for the next four decades, becoming its executive director in 1982 , as well as a co-owner of the enterprise.) Around this time, Peters and Lamantia, together with Donald Allen, traveled by car through the American Southwest, visiting Hopi pueblos and other Native American sites. Such excursions to explore the West, its natural beauty and complex history, continued for the next twenty-five years, becoming an increasingly important source of inspiration for Lamantia's poetic thought and practice. 
In the fall of 1971, Lamantia taught a course on poetics for one term at San Francisco State University at the invitation of Nanos Valaoritis (who, along with his wife, Marie Wilson, had recently relocated to California from Greece). Thanks to Valaoritis's presence on the SF State faculty, literary surrealism had gained an academic foothold in the Bay Area. Valaoritis, who held his position at San Francisco State for many years, was a popular and influential teacher, yet certain members of the decidedly antiacademic Surrealist Movement in the United States became suspicious of what they regarded as Valaoritis's "revisionist" tendencies. Both Valaoritis and Sotère Torregian, an Armenian-American surrealist poet and friend of Lamantia, were criticized by the group for failing to adhere to Breton's allegedly "simple" defi-

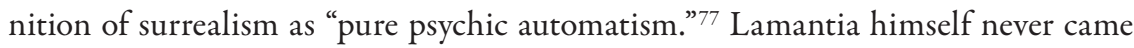
under such criticism, despite the fact that he had called for surrealism to reinvent itself in the very pages of the group's publication Arsenal. In its second volume, published in 1973, Lamantia defined post-Bretonian surrealist poetry as "a rigorous reconstruction against the past, an adamant refusal to be entangled in previously conquered areas of association.... [W] can all the more happily trace our inspirations from ... Breton and Péret ... without literally re-tracing in one's own poetic praxis their inimitable movements [emphasis added]." Nonetheless, besides contributing to Arsenal, Lamantia supported the activities of the group in many ways during this period, from collaborating with them in editing a surrealist section of the 1974 City Lights Anthology to cosigning many of their collective declarations.

In 1976, Lamantia and Peters traveled to Chicago for the World Surrealist Exhibition organized by the Surrealist Movement in the United States. The show featured "over 600 surrealist works - paintings, drawings, photographs, lithographs, collages, sculptures and objects-by nearly 150 active surrealists from 31 countries." 78 Here, Lamantia enjoyed stimulating encounters with older surrealists Leonora Carrington, Gerome Kamrowski, E.F. Granell, Mário Cesariny, and Clarence John Laughlin; and here he met Penelope and Franklin Rosemont and their young Chicago associates for the first time. The Rosemonts, who had been labor organizers in their youth, remained intent on putting surrealism in the service of social revolution, which meant, in their view, building a revolutionary organization. Lamantia was always too self-absorbed for such work, too attentive to his inner transformations: for him, the surrealist revolution was first and foremost a "revolution of the mind."79 The two faces of global surrealism-one looking exoterically outward to political and cultural revolution, the other looking inward to spiritual revelationwere reflected in the Rosemonts' and Lamantia's respective approaches. In politics, Franklin Rosemont then argued for a more orthodox Marxism, and Lamantia took a utopian anarchist position. In spite of their sometimes differing ideas about social organization and surrealist tactics, they were in full agreement about incorporating the "marvelous" into daily life. They were nourished by their many communications, and were to remain lifelong friends. 
Lamantia's long poem "Redwood Highway" from this period gives a clear indication of the direction of his interests: the poem concatenates the European hermetic tradition and Native American thought with Lamantia's new awareness (developed under Peters's guidance) of the deep ecologies of the West Coast. Lamantia now understood nature itself as a magically potent sign system that could both activate and be activated by the poetic imagination. In the notes to another poem from the seventies, "Oraibi" (a Hopi village), the poet refers to the cabala of nature as a "universal unspoken language, easily understood by all.” Through Peters's encouragement, Lamantia, an urbanite who was unfamiliar with wilderness, was learning to enjoy hiking and exploring the wild. Lamantia and Peters were married in 1978 in Nevada, during a trip in which they explored bioregions from the Southwest deserts to the mountains and forests of British Columbia.

Lamantia would gather his poems of the seventies - many of them marked by his newly emerging bioregional sensibility_into a second collection for City Lights, Becoming Visible, published in 198I. The book's title was partly a reference to the becoming-visible of heretofore hidden magical signs in the poet's experience of nature, but it was also partly a reference to the poet's own becoming-visible-that is, to his renewed prominence and participation, following years of hermetic withdrawal, in the local and national poetry community. From 1978 to 1982, Lamantia, at the invitation of the San Francisco Art Institute, taught a well-received course on The Poetic Imagination. He found teaching to be very stimulating, just as he had at San Francisco State. He enjoyed contact with his students and appeared at ease in the classroom, carrying on a wide-ranging discussion of the sources of creativity. During the eighties, Lamantia also engaged more frequently in public readings of his work. In 1980, at the International Poetry Festival in San Francisco, Lamantia shared the stage with his old mentor Rexroth for the last time. Rexroth, whose health was visibly failing (he would die two years later), read from his translations of Japanese poetry, while Lamantia read from the manuscript of Becoming Visible. Although his relationship with Rexroth had been strained at times, Lamantia, in the years following Rexroth's death, always spoke of his old mentor with the greatest respect. ${ }^{80}$

In one sense, Lamantia's earliest mentor had been Edgar Allan Poe; in later years, he enjoyed reading Poe's twentieth-century inheritors, the fantasy-horror writers, among them Fritz Leiber, with whom Lamantia met occasionally in San Francisco, and Clark Ashton Smith, perhaps the most gifted member of a group of Symbolist poets led by George Sterling in World War I-era San Francisco. Around 1980, Peters introduced him to Donald Sidney-Fryer, the executor of Smith's estate. ${ }^{81}$ In 1985, Fryer asked him to speak at the dedication of a Clark Ashton Smith plaque in Auburn, California; Lamantia remarked that Smith was a writer who (much like Lamantia himself) "followed his poetic genius to reveal the heights and depths of a rich cosmic revery." ${ }^{82}$ The mid-eighties were also marked by occasional readings in small venues, and, in 1987, Lamantia and Peters read at the Santa Barbara Poetry 
Festival, organized by his friend Daniel (Abdl-Hayy) Moore, the creator of the Floating Lotus Magic Opera Company, a spectacular ritual theater group in the Bay Area.

A significant turning point for Lamantia during the eighties was his engagement with birding and bird lore, an extension of his ongoing studies of the cabala of the Western biosphere. Lamantia accepted an invitation to read (with Robert Duncan and Susan Griffin) at the 1983 Bisbee Poetry Festival in Arizona so that he could use the occasion to visit a nearby hummingbird refuge. Through binoculars, Lamantia observed, in an epiphanic moment, the dartings of hundreds of hummingbirds: the becoming-visible of the secret, sacred text of nature. One of the festival organizers then led him on a vigorous hike along the San Pedro River, where he was overwhelmed by the sight of so many rare and colorful birds. Lamantia's fascination with what he perceived as their magic potencies and role in culture-manifested in their plumage, their behavior, their songs-continued for the rest of his life.

Whenever possible during this period, Lamantia and Peters sojourned up and down the West Coast, with Lamantia attentive not only to bird life but to all aspects of what, in a poem called "America in the Age of Gold," he termed "mystic geography." This concept he derived from his reading of Native Californian legends in anthropologist and linguist Samuel A. Barrett's Pomo Myths (1933), a book that became as important to Lamantia as Schwaller de Lubicz's Le Temple de l'homme. The exploration of locations crucial to Pomo Indian mythology, such as Clear Lake (including Daladano and Mount Konocti) and Fort Bragg (site of the creation of the world), formed the basis of Lamantia's "many centers of mystic geography," invoking "the time of joy with the supernatural beings" in the pre-Columbian world. Lamantia was fascinated with the extraordinarily poetic metaphysics of Pomo culture, as well as its ethical system, as embodied in the marvelous actions of characters such as Coyote, the creative spirit Madumda, Resin Man, Obsidian Man, and the Squirrel Girls, to name a few that are referenced in his poems. As in Egypt, every animal and stone and imaginal spirit-being had specific meanings, which interrelated in sometimes astonishing ways. But unlike the system of Egyptian symbols, where meanings were recorded on man-made artifacts, in Pomo thought, meanings were embodied in features of the physical world and expressed in a complex and imaginative oral literature. This revelation led to his and Peters's involvement with green politics and bioregionalism, and their friendships with figures in this movement such as Peter Berg and Judy Goldhaft, directors of Planet Drum Foundation.

These influences resulted in Lamantia's final full-length collection of new poems, Meadowlark West (City Lights, 1986), a startling mix of environmentalist agitation and Native American lore with old-world hermeticism and modernist metropolitan sensibilities. Exemplary of his approach is a poem he devoted to "Mt. Shasta," a dormant volcano in Northern California venerated by Native American tribes and surrounded by singular wind and weather patterns; for Lamantia, the mountain was a "locus of dream" aligned with other mythical loci such as Lemuria and the "Whirlpool 
of Ys." Other poems, such as "Wilderness Sacred Wilderness," pursue a similar practice of reading the book of nature for revelatory insights, even as such unlikely protagonists as Nietzsche, Simon Rodia, Man Ray, and Buffalo Bill people the landscape. In keeping with Lamantia's conception of poetry as gnosis, Meadowlark West is dense with reference to his readings in Amerindian myth, Egyptology, alchemy, ornithology, and surrealism-a concise, left-wing riposte to Pound's Cantos. A synthesis and apotheosis of new and lifelong interests, Meadowlark West is, in many ways, Lamantia's most original book.

\section{“EGYPT,”BED OF SPHINXES, AND SYMBOLON}

In 1981, Lamantia had undergone surgery for cancer of the mouth; in 1986, the cancer returned in a metastatic form, necessitating more serious surgery and radiation treatment. After his recovery, he and Peters traveled to New Orleans-where he wrote his contribution to the Annotated Howl-and then along the Gulf Coast. Unfortunately, following this trip, his bipolar illness began to grow much worse. Yet in 1989 he was able to make one final trip abroad, traveling with Nancy to Egypt, where he would experience firsthand the breathtaking iconography that had inspired him for so long: the temples of Luxor and Karnak, the tombs in the Valley of the Kings, and other significant monuments. While in Cairo, he connected with Egyptian writers and also paid a visit to the Mosque of Al-Haqim, the Ismaili imam and teacher of the inner meanings of the Koran. This trip would inspire one of Lamantia's major late poems, "Egypt," which he sometimes considered his masterpiece. Yet this triumph was mitigated by increasing health problems. By 1990 he was suffering periods of prolonged and incapacitating depression, punctuated by disruptive manic episodes, a state of affairs that would endure through mid-decade.

In 1997, however, City Lights released a new selection of his work, Bed of Sphinxes: New and Selected Poems 1943-1993, which gathered a small number of important uncollected pieces including "Egypt," "Poem for André Breton," "Diana Green," and "Passionate Ornithology Is Another Form of Yoga." Yet even as it looked back at fifty years of poetry, Bed of Sphinxes would herald Lamantia's emergence from his state of depression into a new flurry of poetic activity.

This emergence was precipitated by a mystical vision Lamantia had at the National Shrine of St. Francis in North Beach, San Francisco, where in 1998 holy relics of St. Francis and St. Clare were put on display. ${ }^{83}$ As he writes in a third-person note among his papers: "August 15, 1998: While on a casual visit to the newly designated (now National) Shrine Church of St. Francis of Assisi, poet Philip Lamantia experienced an unprecedented sense of unity with the-divine-in-the-human, renewing his Catholic Christian practice, inspirational source for his subsequent poetry." During this vision, as he related to Nancy, the shrine became suffused with bright 


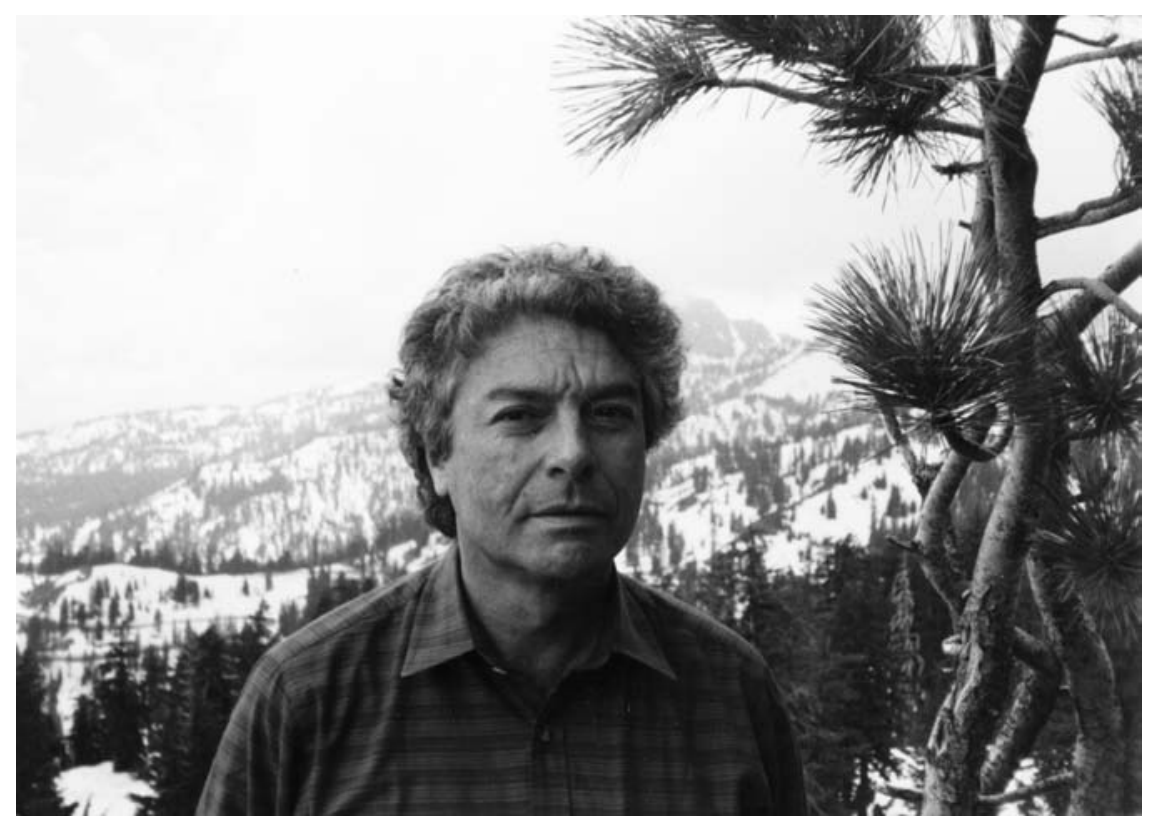

At Mount Shasta, California, 1986. Author photo by Nancy Joyce Peters for Lamantia's Meadowlark West. Courtesy of The Bancroft Library, University of California, Berkeley.

light, and Lamantia was convinced the experience emanated from the relics. In the immediate aftermath of this experience, Lamantia was stricken with a terrifying and uncontrollable manic episode. Once he became more stable, he found refuge in the ritual of the Mass, and also broke his long poetic silence, writing poetry once again. Unsurprisingly, these final poems of Lamantia's are frequently religious and devotional in nature.

As he accumulated poems, Lamantia began to contemplate a new collection to

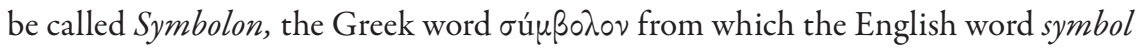
derives, composed from the root words $\sigma$ úv- (sym-), "together," and $\beta 0 \lambda \eta$ (bolé), "a throw," thus, "thrown together." For Lamantia, symbolon was a multifaceted concept, reaching into the very mechanism of language itself, as he writes in "Theoria": "words are eidetic/perceptions of a synthesis / of symbolons-'things'/thrown together." On an esoteric level, symbolon evoked the "symbolique" of Schwaller de Lubicz. "The symbolique includes imaged writing as well as gestures and colors, all aimed at transcribing in a functional manner the esoteric significance of a teaching whose inner meaning remains inexpressible by any other form," Schwaller de Lubicz writes in Sacred Science, citing by way of example the Catholic symbolization of the concept of the "divine Trinity" as a triangle. "Here there is symbolique," he 
continues. "It pertains to an unobjectifiable fact and a creative function at the same time.... [T] he symbolique is the means of evoking the intuition of a function which eludes rationalization; it therefore applies only to theogony, to theology, to sacred science, in fine, to knowledge of a world of causes." ${ }^{84}$ From here it is not difficult to link this "function which eludes rationalization" to surrealism, for notably, during this final poetic phase, Lamantia found himself able to synthesize his experiences as a Catholic and as a surrealist, even asserting, in one of the last poems he wrote, that "God is a surrealist / in the union of opposites."

During this brief period of activity, from late 1998 through late $200 \mathrm{I}$, Lamantia published three new poems, "Ultimate Zone," "Seraphim City," and "Triple V: The day non-surrealism became surrealist," and gave readings in New York City, Los Angeles, and San Francisco. His last major public event occurred at City Lights on September 20, 200I, at which he read once again the poems of John Hoffman, as well as a handful of his own. Yet before the end of the year, he would once again fall victim to depression. The Mass was no longer a conduit for revelation, and he was increasingly disappointed in the church, which was not moving toward liberation theology, the "civilization of love" he had hoped for. He ceased to write, see friends, or appear publicly. During the next few years of seclusion, however, he gave more thought to his Symbolon project. Reviewing crucial touchstones of his long poetic and spiritual journey, he was finding compelling relationships among all his diverse paths to transcendent understanding, and he envisioned writing a long poem that would be an inclusive synthesis. However, he wrote down only a few rough notes and some fragments of poetry, and did not live to create this work, dying suddenly of heart failure on March 7, 2005.

\section{CONCLUSION}

Although his hermetic nature has sometimes obscured his role in literary history, Philip Lamantia was one of the most significant American poets of the twentieth century. Quite aside from his status as a child prodigy and as the only American poet welcomed into the surrealist movement during André Breton's exile in New York City, he arrived as a truly singular, romantic figure in I940s American poetry, at a time when the high modernism of the I9Ios through the I930s was being repudiated or tamed by academic poetry as embodied by the New Criticism. As we have seen Rexroth observe, Lamantia's work pointed the way to the future new American poetry of the I950s and beyond. And, along with Yves le Pellec, we can justifiably assert that Lamantia and his work constituted a direct and important link between the radical culture of European modernism in the first half of the century and the radical American counterculture of the second.

As those who knew him can attest, Philip Lamantia was an extraordinary person. When not disabled by depression, he was a magnetic presence, both charismatic 


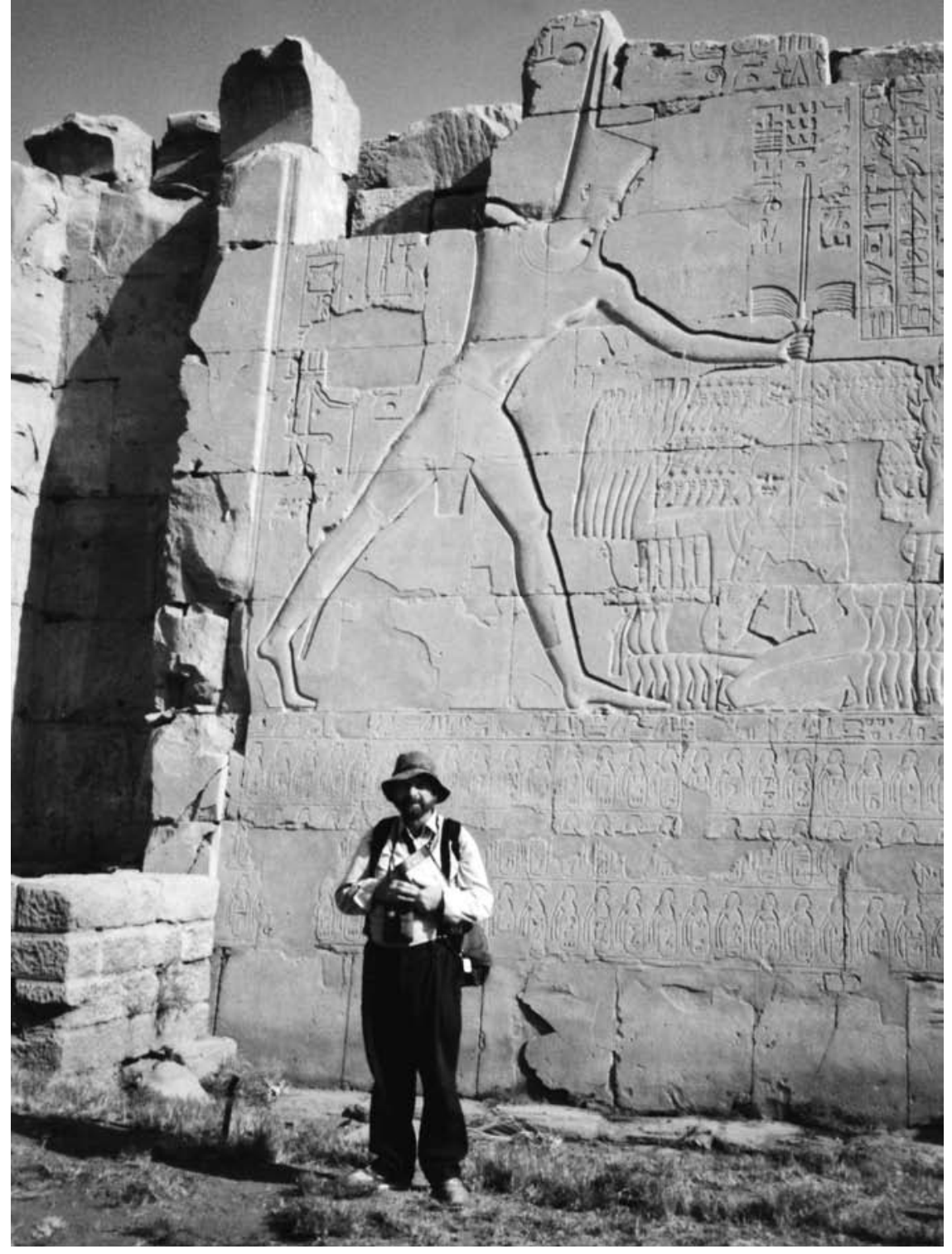

At the Temple of Luxor, 1989. Photo by Nancy Joyce Peters. Courtesy of The Bancroft Library, University of California, Berkeley. 


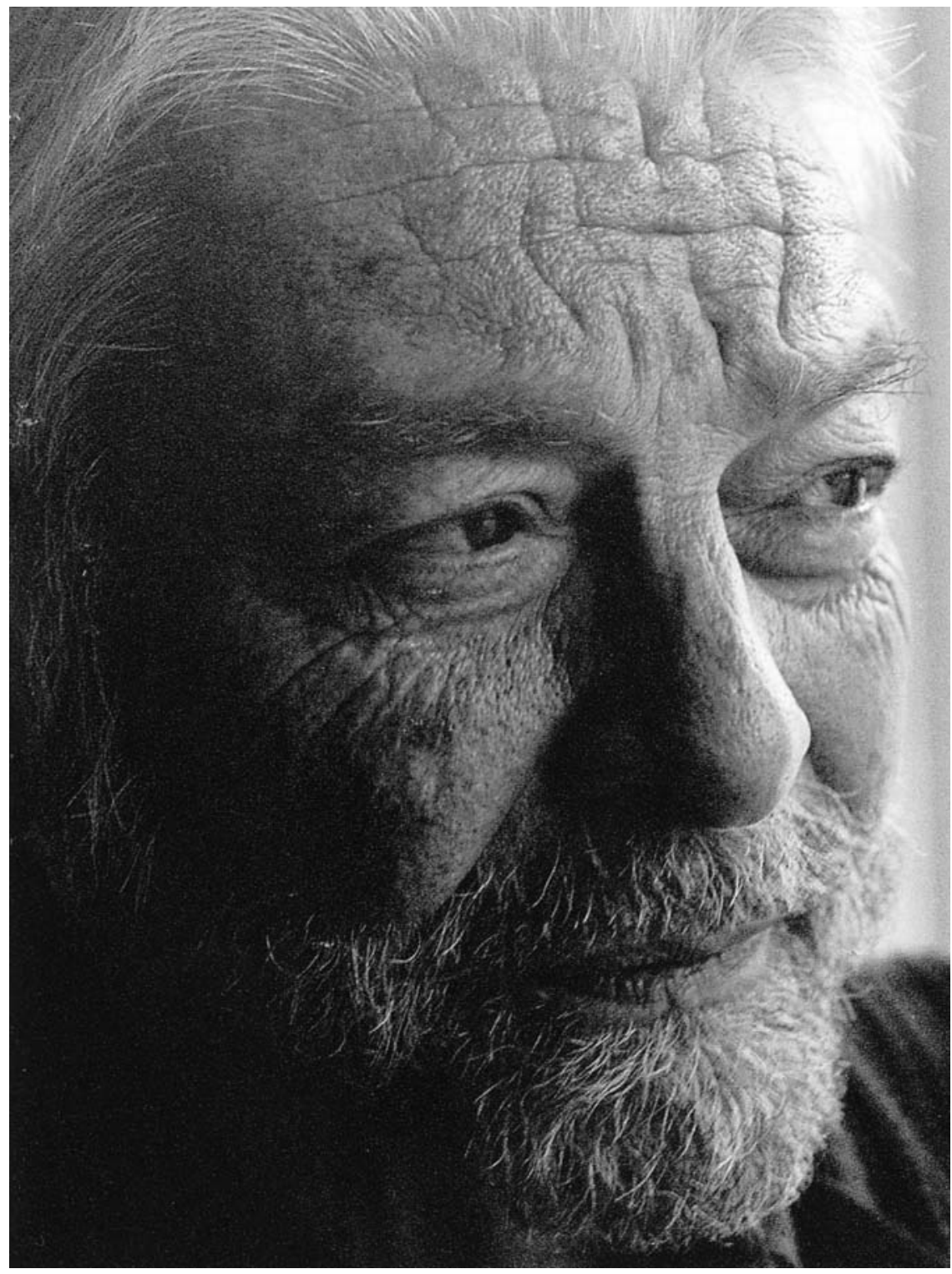

At home in San Francisco, December 2000. Photo by John Suiter. (C) John Suiter. Courtesy of The Bancroft Library, University of California, Berkeley. 
and charming. While his formal education ended with his high school diploma, the breadth and depth of his erudition, as well as his recall, were astonishing, and he could discourse freely on a bewildering variety of topics, from art, music, and literature, to utopian, anarchist, and Marxist thought, to world religions, renaissance hermeticism, medieval alchemy, and Egyptology, to ornithology, California natural history, and Native American culture, to surrealism, of course, and, most fundamentally, to poetry. His discourses weren't so much linear as spiral, taking so circuitous a route through history and geography you'd forget what he was talking about until you were suddenly struck by an unexpected return to the subject from whence he'd begun - a process that sometimes took hours. Although he could discourse cogently, as a writer he conducted his intellectual life almost exclusively through poetry, manifesting the fruit of his knowledge in the poem itself.

Poetry for Lamantia was both an expression and a form of gnosis. The esoteric nature of his researches makes some of his poetry difficult, much as it does with, say, Yeats, from whom Lamantia borrowed the title phrase of his book The Blood of the Air. The phrase is significant, for it hints at the vitality that runs through even the most opaque poems of both these poets. In Whitman's Wild Children, Neeli Cherkovski makes a telling observation when he writes: "Breton, Péret, Rimbaud, Lautréamont ... they didn't exist in history for Lamantia; they were contemporaries. He brings them alive in his small, crowded studio just as he does in his poetry." 85 Cherkovski might have easily said Nicholas Flamel, Teresa of Ávila, Frederick II of Sicily, or Apollonius of Tyana-and by "bringing them alive" he doesn't mean portray, for the history and ideas of such figures were relevant to Philip's everyday life, inasmuch as his life was a continual search for enlightenment. Ancient ideas were as alive to him as contemporary matters. He was essentially a mystic, concerned with the eternal rather than the ephemeral, to the occasional detriment of practical, daily existence.

Lamantia's way of being-his wants and needs, his conversation and demeanorwas as tumultuously imaginative as his poetry. He was one of those rare poets who dwelled perpetually within the Poem, whose life was coterminous with poiesis. This places him and his work in opposition to the two dominant paradigms of American poetics that view poetic practice either as a personal expression (the mainstream model) or as a critique of socially constructed meaning (the avant-garde model). Lamantia's work-in all phases of its development, as the poems collected here demonstrate- both achieves these aims and goes beyond them. For Lamantia, the poetic Word was transcendent, exceeding the limits of self and society to participate in a cosmic and even divine order. He fulfilled the definition of the poet, handed down from antiquity, as one possessed by "divine madness." His work points the way to the future of poetry as a medium once more integrated with the very sources of being, as the earthly manifestation of an inexhaustible Mystery. 


\section{NOTES}

I. David Meltzer, ed., San Francisco Beat: Talking with the Poets (San Francisco: City Lights, 200I), 142 .

2. Kenneth Rexroth, American Poetry in the Twentieth Century (New York: Herder and Herder, 1971), 165 .

3. Christopher Lehmann-Haupt, "Philip Lamantia, 77, Surrealist Poet, Is Dead," March 21, 2005, www.nytimes.com/2005/03/21/arts/2rlamantia.html, accessed November 29, 2012.

4. Philip Lamantia, "Radio Voices: A Child's Bed of Sirens," in "Surrealism \& Its Popular Accomplices," Cultural Correspondence I0-1I (Fall 1979): 25-31.

5. Ibid., 25 .

6. Ibid., 26 .

7. André Breton, Manifestoes of Surrealism, trans. Richard Seaver and Helen R. Lane (Ann Arbor: University of Michigan Press, 1972), 27.

8. He refers to the visual effects of advection fog, common to the southern neighborhoods of the city.

9. There is an exact resonance between Lamantia's title "Paranoid Dream" and a phrase attributed to Dalí-“a dreamed itinerary of new paranoic phenomena"-that appears in Gascoyne's Short Survey of Surrealism, a book that exercised a great influence on the young Lamantia.

Io. Indeed, Lamantia had brought a set of colored pencils with him to San Bruno Mountain, perhaps intending to sketch, and instead ended up using the pencils to write his first original poem.

II. Meltzer, San Francisco Beat, 135 .

I2. Nancy Joyce Peters, "Philip Lamantia," in Dictionary of Literary Biography (Detroit: Gale Research, 1982), 330.

13. Kenneth Rexroth, An Autobiographical Novel (New York: New Directions, 1991), 510.

14. Meltzer, San Francisco Beat, 135-36.

I5. See Garrett Caples, "André Breton and Philip Lamantia," in Titanic Operas, Folio III: Poetries and New Materialities II, ed. Joseph Donahue, http://archive.emilydickinson.org/titanic/material/ three/caples.html, accessed January 9, 2013.

16. Catrina Neiman, "Introduction," in View: Parade of the Avant-Garde, ed. Charles Henri Ford (New York: Thunder's Mouth, 199I), xii.

17. Cited in Dickran Tashiian, A Boatload of Madmen: Surrealism and the American Avant-Garde 1920-1950 (New York: Thames and Hudson, 1995), 254.

18. Tashjian, Boatload of Madmen, 137.

19. Though he quit the editorial staff, Lamantia would remain a "Contributing Editor" on the masthead of View until his definitive break with Charles Henri Ford in March 1946 over what he saw as the magazine's increasing sensationalism.

20. Meltzer, San Francisco Beat, 136 .

21. As early as its December 1943 issue (no. 4, series III), View had announced the projected publication of Lamantia's surrealist poems under its new View Editions imprint, which in 1946 would issue the first single-volume English translation of André Breton's poetry, Young Cherry Trees Secured against Hares, with a cover by Marcel Duchamp. Lamantia's book was to have been titled 
First Poems, with a cover by Max Ernst, but this plan was complicated by tensions between Ernst and Breton and ultimately scuttled by Lamantia's 1946 break with Charles Henri Ford and View.

22. Michael Davidson, The San Francisco Renaissance: Poetics and Community at Mid-century (Cambridge: Cambridge University Press, 1989), 38.

23. Meltzer, San Francisco Beat, 139.

24. See Lewis Ellingham and Kevin Killian, Poet Be Like God: Jack Spicer and the San Francisco Renaissance (Hanover, NH: Wesleyan, 1998), 21. Ellingham and Killian identify this address as McKinley Street, though it's actually McKinley Avenue.

25. In an autobiographical note among his papers, under the heading "1948," Lamantia writes: "Discovery of R\&B 'Little Harlem' later described in Kerouac's On the Road as one of two SF sites of jazz and R.B. musical culture. Important contacts with genius Harry Smith, painter \& ethnomusicologist-very important exchanges between us re magic, gnosis, \& music-Nights of 'Jackson's Nook' \& Jimbo's Bop City within Fillmore, \& Post \& Buchanan.'

26. Philip Lamantia and John Hoffman, Tau and Journey to the End (San Francisco: City Lights, 2008), 58 .

27. Ibid., 59 .

28. Ibid., 59-60.

29. Peters, "Philip Lamantia," 33 I.

30. Tau and Journey to the End, 64.

31. Peters, "Philip Lamantia," 332.

32. Bill Morgan, I Celebrate Myself: The Somewhat Private Life of Allen Ginsberg (New York: Viking, 2006), 152.

33. John Suiter, "Philip Lamantia Interview, North Beach, December II, 2000," Carton 21, Folder 23 of the Philip Lamantia Papers, 1944-2005 (BANC MSS 2006/179) at The Bancroft Library at the University of California, Berkeley), p. 6.

34. John Suiter, Poets on the Peaks: Gary Snyder, Philip Whalen and Jack Kerouac in the North Cascades (Washington, D. C.: Counterpoint, 2002), il 4.

35. Suiter, Poets on the Peaks, II 4.

36. Suiter, "Philip Lamantia Interview," 2. De Angulo had died in 1950.

37. Suiter, Poets on the Peaks, II5-16.

38. Jack Kerouac, Selected Letters, 1940-1956 (New York: Penguin, 1995), 349-50.

39. Jack Kerouac, Desolation Angels (New York: Riverhead Books, 1995), 206-8.

40. Allen Ginsberg, Howl and Other Poems (San Francisco: City Lights, 1956), 9.

4I. Allen Ginsberg, Howl: Original Draft Facsimile, Transcript and Variant Versions, Fully Annotated by Author, with Contemporaneous Correspondence, Account of First Public Reading, Legal Skirmishes, Precursor Texts and Bibliography, ed. Barry Miles (New York: HarperPerennial, 1986), I24. Another account of this incident appears in Lamantia's uncollected 1961 poem "Visions."

42. Morgan, I Celebrate Myself, 202.

43. Suiter, "Philip Lamantia Interview," I6.

44. Ibid., 23. 
45. Ibid., 42.

46. It is likely that Lamantia would have destroyed the manuscript of Tau, as he had done with many of his other writings, if not for the intercession of his first wife, Goldian Nesbit, who implored him to preserve "this beautiful manuscript." See Garrett Caples, "A Note on Tau," in the Pocket Poets edition of Tau (San Francisco: City Lights, 2008), 7.

47. Jack Kerouac, The Dharma Bums (New York: Penguin, 2006), Io.

48. Michael McClure, Scratching the Beat Surface (New York: Penguin, 1994), I2.

49. As Lamantia told Suiter in their interview, "I really got to know Jack after the Howl reading and then when he came to stay with me, which was not long after." Lamantia insisted, too, that Kerouac "was virtually in the Church when he spent those few weeks with me when I was very fervent." Suiter, "Philip Lamantia Interview," 35-36.

50. Ibid., 209.

5I. Interview with Lamantia in Meltzer, San Francisco Beat, I40.

52. Tau and Journey to the End, $\mathrm{I} 2$.

53. New York Post, January 22, 1958. Thanks to Steven Fama for providing this citation.

54. "Beat Mystics," Time, February 3, 1958.

55. Paul O’Neil, “The Only Rebellion in Town," Life, November 30, 1959, I23.

56. In fact, they were married twice, in a civil ceremony in Crawford, Texas, in 1960 , and then in a Catholic rite in Mexico in 1961 .

57. This circumstance is referred to in "Peroxide Subway" in Destroyed Works (San Francisco: Auerhahn, 196I): "66 days in Huntsville Prison." According to Lamantia, he was searched and busted merely for a stray marijuana seed that was found in his one of his pant cuffs.

58. This incident is documented in Lamantia's previously uncollected poem, "Ceylonese Tea Candor (Pyramid Scene)," from which the quoted terms are drawn.

59. This is broadly but not strictly true, as the final poem of the volume, "Binoculars," refers to people like Gregory Corso, whom Lamantia met sometime after the Six Gallery reading.

60. Michael McClure, Meat Science Essays, 2nd ed. (San Francisco: City Lights, 1966), 10. The essay "Phi Upsilon Kappa" originally appeared in Kulchur 8 (Winter 1962), but didn't appear in Meat Science until the decision in Grove Press Inc. v. Gerstein (1964) lessened the potential to prosecute literary publishers on obscenity grounds. (The essay is partly devoted to the word "Fuck.") McClure, who found the word aelf-scin, meaning "shining like an elf," in an Anglo-Saxon dictionary, likens this to Lamantia’s weir.

6I. This book, for example, includes "Deamin," whose original title was simply "Weir."

62. Tau and Journey to the End, 123 .

63. It appears Lamantia sent the manuscript to Auerhahn in late 1960-hence the date of his "Note on Destroyed Works"-though the book wouldn't be printed until 1962.

64. Lamantia's Auerhahn books are unpaginated, but this poem is the sixth section of the opening suite, "Hypodermic Light."

65. Peter Conners, The White Hand Society: The Psychedelic Partnership of Timothy Leary and Allen Ginsberg (San Francisco: City Lights, 2010), I54.

66. Autobiographical notes, Carton II, Folder II, of the Philip Lamantia Papers, 1944-2005 (BANC MSS 2006/179) at The Bancroft Library at the University of California, Berkeley. 
67. Previously, during the period of his ostensible silence, Lamantia had written a longer poem, "Kosmos," relating to his LSD experiences, but deemed it unworthy of publication.

68. Nancy Joyce Peters, address at the memorial for Philip Lamantia, San Francisco, March 31, 2005.

69. The back-cover copy further stated that, after Lamantia was "welcomed by André Breton into the Surrealist movement," there "followed a long, transitional period of mystical orientations \& silences."

70. José Pierre, Tracts surréalistes et déclarations collectives (Paris: Terrain Vague, 1982).

7I. In his 1973 prose statement "Between the Gulfs," Lamantia wrote: "From having initially found the key (the road opening, 1943-1946) to having lost the key (the road closed down, 1946-1966) and since rediscovering the key (the road re-opening in 1967), my solidarity with the surrealist movement ... re-invents itself without the slightest ambiguity." Arsenal 2, no. 2 (1973): 32.

72. See Andrew Joron, Neo-Surrealism; Or, The Sun at Night: Transformations of Surrealism in American Poetry 1966-19g9 (Oakland, CA: Kolourmeim, 2010).

73. See Ron Sakolsky, ed., Surrealist Subversions: Rants, Writings and Images by the Surrealist Movement in the United States (Brooklyn, NY: Autonomedia, 2002).

74. Lamantia's long essay "Poetic Matters," published in Arsenal 3 (1976): 6-10, stands as one of the clearest statements of his own poetics while offering a sustained critique of the American poetry scene in the midseventies.

75. A decade earlier, Donald Allen had included selections from Lamantia's work in the landmark anthology The New American Poetry: 1945-1960 (Grove Press: New York, 1960).

76. The book's epigraph gives a definition of "Lamantines" as a species of "mermaid-like mammals native to Africa.... They play, in West-African myth, a role similar to that of the Sirens in Europe." It is telling that the listing of previous books by Lamantia on the copyright page of The Blood of the Air includes only the two published after his return to surrealism in the midsixties.

77. See Pete Winslow, "What American Surrealism Is Fanatical About," in The Forecast Is Hot: Tracts and Other Collective Declarations of the Surrealist Movement in the United States 1966-1976 (Evanston, IL: Black Swan Press, 1997), in.

78. Ron Sakolsky, “Surrealist Subversion in Chicago," in Surrealist Subversions, 79.

79. This phrase occurs in Breton's Second Manifesto of Surrealism, written in the wake of the Paris group's failed attempt to join forces with the Communist Party.

80. Lamantia attempted in 1999 to write a poem, entitled "Mentor," about his relationship to Rexroth (the poem begins: "An old mentor mourned/many a night you opened / with the ancient learning we / met eternity at its only juncture / for the living"), but left it unfinished.

81. Peters had contacted Sidney-Fryer in the course of writing, with Lawrence Ferlinghetti, Literary San Francisco (San Francisco: City Lights / Harper \& Row, 1980).

82. "Clark Ashton Smith Plaque Dedication," in Philip Lamantia papers, 1944-2005, The Bancroft Library, BANC MSS 2006/179, Carton 17, Folder 38.

83. "A Short History of Saint Francis of Assisi Church," www.shrinesf.org/history.html, accessed November 29, 2012.

84. R. A. Schwaller de Lubicz, Sacred Science: The King of the Pharaonic Theocracy (1961), trans. André and Goldian VandenBroeck (Rochester, VT: Inner Traditions, 1988), I2O.

85. Neeli Cherkovski, Whitman's Wild Children (South Royalton, VT: Steerforth Press, 1999), I28. 
This page intentionally left blank 